\title{
Rıdvan Ağa'dan Süleyman Bey’e (I634-I774): Osmanlı Elçilik Heyetlerinin Avusturya Devlet Arşivindeki İzleri
}

\author{
Hüseyin Onur Ercan*
}

From Rıdvan Ağa to Süleyman Bey (1634-1774): The Traces of the Ottoman Delegations in the Austrian State Archive

Abstract - With the inclusion of Buda in 1541 as a province of the Ottoman Empire, the Ottomans and the Austrian Habsburgs became neighbors and after the Peace of Zsitvatorok (1606) the diplomatic traffic between the two powers increased. Among the basic sources for studying the Ottoman-Habsburg diplomatic relations from their beginnings at the end of the XVth century are the Austrian State Archives. Besides the politically important documents, there are also numerous documents that shed light on the increasing number of accommodations of various Ottoman delegations who stayed in Vienna as guests $\left(\mathrm{XVII}^{\mathrm{th}}-\mathrm{XVIII}{ }^{\mathrm{th}}\right.$ centuries). Until the Treaty of Sistova (1791) that ended the Ottoman-Habsburg military confrontations definitely, approximately ninety Ottoman legations were sent to Vienna. In the present study, the focus is on the delegations sent between the years 1634 to 1774 and on the question of how and where they were accommodated by the Habsburg institutions as well as who was their responsible host. In this paper, an endeavor is made to conduct a study of Ottoman-Habsburg diplomatic history by combining the data revealed so far with information from some pertinent documents of the Austrian State Archives.

Keywords: Ottoman, Habsburg, Ottoman delegation, diplomacy, accommodation, administrative history, Vienna, XVII ${ }^{\text {th }}-X V I I I^{\text {th }}$ centuries, Austrian State Archive.

\footnotetext{
* Türk-Alman Üniversitesi.
} 


\section{Giriş}

Osmanlılarla Habsburglar ${ }^{1}$ arasındaki muharebelerde Osmanlıların kesin üstünlüklerinin yerini beklenmedik biçimde uzun soluklu, askerî ve malî açıdan yıpratıcı savaşların alması keyfiyeti, bu savaşlar neticesinde akdedilen ateşkes/barış antlaşmalarının müzakere şeklini ve muhtevasını etkilemişti. Bu etki ilk defa Zitvatorok (Jitva Boğazı) Antlaşması'nda göze çarpar (1606). Zira XV. yüzyılın son çeyreğinde başlayan ${ }^{2}$ Osmanlı-Habsburg diplomatik ilişkilerinin seyri ${ }^{3}$ ve Devlet-i Aliyye'nin diplomasi pratikleri artık kabuk değiştirmişti: Osmanlıların müzakereleri ilk defa serhadde tarafsız bir sahada gerçekleştirdikleri bu antlaşma ${ }^{4}$ ile yazışmalarda Habsburg kayzerleri için kullandıkları unvan, ${ }^{5}$ Habsburglardan 1547 'den beri aldıkları haraç $\left(\right.$ Tribut) ${ }^{6}$ ve iki devletin protokoldeki haklar1 ${ }^{7}$ meseleleri ele alınmış ve yine ilk defa olmak üzere büyük bir elçilik heyetiyle (Magnus Legatus) antlaşma metninin mübadelesi öngörülmüştü. ${ }^{8}$ Ayrıca gönderilecek Osmanlı elçilerinin bundan evvelki gibi düşük rütbelerdeki saray hizmetkârları yerine en aşağı sancak beyi seviyesindeki yüksek rütbelilerden oluşması kararlaştırılmıştı. ${ }^{9}$ Bunun

1 Makale boyunca "Habsburg" ifadesi, Avusturya Habsburglarını (Casa de Austria) tanımlamak için kullanılmıştır.

2 Karl Teply, “Türkische Gesandtschaften nach Wien (1488-1792)”, Österreich in Geschichte und Literatur, XX (1976), s. 17.

3 Markus Köhbach, "Die diplomatischen Beziehungen zwichen Österreich und dem Osmanischen Reich (Vom Frieden von Zsitva Torok bis zum 1. Weltkrieg)”, Osmanlı Araştırmalar, 4 (1984), s. 237.

4 Fatih Yeşil, “Aydınlanma Çă̆ında bir Osmanlı Kâtibi: Ebubekir Râtib Efendi (1750-1799)”, (İstanbul: Tarih Vakfi Yurt Yayınları, 2011), s. 14 dipnot 14.

5 Markus Köhbach, "Çasar veya İmparator: Jitvatorok Antlaşması’ndan (1606) sonra Roma kayserleri'nin Osmanlılar tarafından telakkubu hakkında”, çev. Yusuf A. Aydın, İstanbul Üniversitesi Edebiyat Fakültesi Tarih Dergisi, 37 (2002), s. 159-169.

6 Ernst D. Petritsch, "Tribut oder Ehrengeschenk? Ein Beitrag zu den habsburgischosmanischen Beziehungen in der zweiten Hälfte des 16. Jahrhunderts", Archiv und Forschung. Das Haus-, Hof- und Staatsarchiv in seiner Bedeutung für die Geschichte Österreichs und Europas, hg. von Elisabeth Springer, Leopold Kammerhofer (Wien, München: Verlag für Geschichte und Politik, 1993), s. 5.

7 Feridun M. Emecen, "Çağdaş Osmanlı Kaynaklarında Uzun Savaşlar ve Zitvatorok Antlaşması ile İlgili Algılama ve Yorum Problemleri”, Osmanlı Araştırmaları, 29 (2007), s. 97.

8 Kemal Beydilli, “Sefaret ve Sefaretnâme Hakkında Yeni Bir Değerlendirme”, Osmanlı Araştırmalar, 30 (2007), s. 17.

9 Kemal Beydilli, "Sefâretnâme”, TDV İslâm Ansiklopedisi (DİA), 2009, XXXVI, 291. 
neticesinde büyükelçilere verilen pâye Rumeli veya Anadolu beylerbeyilikleri iken ortaelçiler nişancılık veya defterdarlık pâyesi taşırdı. ${ }^{10}$

1547 'de beş, ardından dokuz defa sekizer yıllık müddet için geçerli olması yönünde mutabık olunan barış antlaşmalarından ${ }^{11}$ sonra ilk defa yirmi yıllık geçerliliğiyle de diplomatik ilişkilerdeki değişimi gösteren Zitvatorok Antlaşması neticesinde her ne kadar ciddî bir toprak kaybedilmemişse de, Muhteşem Süleyman'dan bu yana sahip olunan psikolojik üstünlüğün sarsıldığını söylemek isabetsiz olmayacaktır. Dönemin Osmanlı tarihçileri ve münevverleri nezdinde hâlâ Osmanlı devasa gücü sürse de ${ }^{12}$ karşı tarafta Osmanlılara, dolayısıyla "Hıristiyanlığın baş düşmanı Türklere"13 karşı elde edilmiş böylesine müspet bir gelişmeyi nesillerdir bekleyen Alman basını sıcağı sıcağına ve yüzyıl içerisinde birçok yayınla, Habsburgların Osmanlılarla olan ilişkilerindeki bu yeni veçheyi Hıristiyan Avrupa kamuoyunda lehlerine hem siyasî hem dinî bir propaganda malzemesi yapmaktan geri kalmad. ${ }^{14}$

XVII. yüzyılın başındaki bu ilklerle birlikte yüzyılın ikinci yarısında Osman1-Habsburg cephesinde yaşanacak yeni savaşlar, gücün tek taraflı bir vaziyetten "denge" konumuna kaydığını belirginleştirerek ${ }^{15}$ Osmanlıları Habsburglarla olan ilişkilerinde eski alışkanlıklarını tedricen terk etmeye ve eskiden uygulamaya ihtiyaç duymadıkları bir diplomatik anlayışı tecrübe etmeye zorlayacaktır. Artık iki ezelî hasmın (Erb- und Erzfeinde) cephedeki mücadelelerine "diplomasi" adında yeni bir cephe eklenecek ve Osmanlılar, ilişkilerini ordu ile yürütmeye alışık olduğu siyasal rakibi karşısında diplomasi dilini daha önce yapmadıkları bir şekilde

10 Güneş Işıksel, "Yirmisekiz Çelebi Mehmed Fransa'da: Güzergâh, toplumsal algı, diplomatik pratikler ve de "Lâle Devri”", Doğu Batı Düşünce, 21 (2018), s. 110.

11 1553, 1559, 1562, 1565, 1568, 1573, 1576, 1584 ve 1591 (Dariusz Kołodziejczyk, Ottoman-Polish diplomatic relations (15th - 18th century), (Leiden [u.a.]: Brill, 2000), s. 83.

12 Emecen, "Çağdaş Osmanlı Kaynaklarında", s. 97.

13 Aslı Ç1rakman, From the "terror of the world" to the "sick man of Europe": European images of Ottoman Empire and society from the sixteenth century to the nineteenth, (New York [et al.]: Peter Lang, 2002), s. 85.

14 Bir örnek için bkz. Friedens Conditiones, wie dieselben zwischen dem Römischen vnnd Türkischen Keyser, Rudolpho dieß Namens dem andern, und Hehomath Sultan dem ersten [...], (Prag: Johan Ottmari Jacobi, 1607 [Mit Bewilligung Nachgedruckt zu Nürnberg durch Christoff Lochner, 1607]).

15 Bu durumun vazıh bir göstergesi için bkz. Özgür Kolçak, “... Cümle Palankaları Küffâr Aldı...” 1663-64 Osmanlı-Habsburg Savaşında Dezenformasyon, Propaganda ve Siyasi İktidar, Osmanlı Araştırmaları, 43 (2014), s. 165-192. 
kullanmaya çalışacaktır. Bunun somut örneğini, Osmanlı sarayı adına yapılan elçilik heyetlerinin hem sayıca artması ${ }^{16}$ hem ikamet sürelerinin uzamasında görmek mümkündür.

Diplomatik mütekabiliyeti sağlama çabası diplomatik ilişkilerin birçok yönüne olduğu gibi barış antlaşmalarının teyid ve tecdidinin tasdiki için yanlarındaki tasdiknâme metnini (Ratifikation) teslim etmek üzere gönderilen Osmanl1-Habsburg büyükelçilerinin gerçekleştirdikleri resmî mübadele (Botschafteraustausch) merasimlerine de aksetti. Bu merasim ilk defa 1628'de Hans Ludwig von Kuefstein ile Receb Paşa’nın mübadelesi sırasında ${ }^{17}$ Osmanlıların sınır kalesi Estergon (Esztergom) ile Habsburgların elinde bulunan sınır noktası Yanıkkale (Győr) arasında yer alan, Tuna Nehri kenarında ve Komaran (Komárom) yakınındaki Szöny köyü civarında yapıldı. XVII.-XVIII. yüzyıllarda iki devlet arasındaki sınırlar ve buna bağlı olarak mübadelenin yapılacağı ve tarafsız olduğu düşünülen bölge değişse de ${ }^{18}$ değişmeyen şeylerden biri merasimin ne şekilde gerçekleştirileceğinin önceden, barış görüşmeleri sırasında diplomatlar ve müzakereciler tarafından görüşülüp çerçevesinin ve ince detaylı içeriğinin belirlenmesiydi. 1719 yllına gelindiğinde -model olarak Kara Mehmed Paşa ve Walter Leslie'nin 1665 'teki mübadelesi kullanılmıştı- eşitliği (Parität) sağlamak için artık adım hesaplarının yanında matematiksel ölçümlere de başvurulmuştu. Buna rağmen devlet temsilcilerinin birbirlerinin üzerine üstünlük kurma ve böylece kendi devletini onurlandırma çabaları, yoğun bir sembolizm kullanmak suretiyle de olsa devam ediyordu. ${ }^{19}$ Ancak galip gelen kim olursa olsun, merasim sonunda elçiler birbirleriyle musâfaha ederek vedalaşırlard ${ }^{20}$ ve böylece orada karşılaşmalarının nedeni olan "barış" tüm şahitler huzurunda hatırlanırdı.

16 Beydilli, "Sefaret ve Sefaretnâme", s. 18-19.

17 Teply, "Türkische Gesandtschaften”, s. 19.

18 Mübadele yeri Karlofça Antlaşması'na kadar Szöny (1606-1699), Pasarofça Antlaşması’na kadar Salankamen (1700-1718), Belgrad Antlaşması'na kadar Paraćin (1719-1739) ve ardından Belgrad yakınındaki Zemun (Semlin) olmuştu.

19 Arno Strohmeyer, "Die Theatralität interkulturellen Friedens: Damian Hugo von Virmont als kaiserlicher Großbotschafter an der Hohen Pforte (1719/20)", Frieden und Friedenssicherung in der Frühen Neuzeit: Das Heilige Römische Reich und Europa. Festschrift für Maximilian Lanzinner zum 65. Geburtstag, hg. von Guido Braun, Arno Strohmeyer, (Münster: Aschendorff, 2013), s. 418-424.

20 Abubekir Sıddık Yücel, "Mühürdar Hasan Ağa’nın Cevâhirü’t-Tevârîh’i” (doktora tezi), Erciyes Üniversitesi, 1996, s. 299. 
Büyükelçilik heyetlerinin mevcudunda da mütekabiliyete dikkat edilirdi. 1650'de Viyana'ya gönderilen Hasan Paşa 144 kişilik bir heyete sahipken ${ }^{21}$ Habsburglar adına İstanbul'a gönderilen Rudolf Schmid'in heyeti 150 kişiden müteşekkildi.. ${ }^{22} 1665$ 'te heyet sayısı 299'a ${ }^{23}$ (Kara Mehmed Paşa) karşıllk takriben $350{ }^{\prime} \mathrm{ydi}^{24}$ (Walter Leslie). Benzer durum hemen her büyükelçilikte, ${ }^{25}$ sayının bir hayli arttığı XVIII. yüzyılda da sürdü. Bilindiği gibi iki devlet arasındaki son büyükelçilik teatisi aynı zamanda heyet mevcudunun sayıca zirvesini teşkil ederek 1740'ta Belgrad Antlaşması sonrasında Cânibî Ali Paşa (922 kişi) ile Anton Korfiz Graf Ulefeld (yaklaşık 1000 kişi) ${ }^{26}$ tarafından yapılmıştı. Bu son örnekte de sayıların birbirine yakın tutulmaya çalışıldığı ortadadır.

\section{Osmanlı Elçilik Heyetleri ve Viyana'daki İmparatorluk Arşivindeki İzleri}

Osmanlı-Habsburg diplomasi tarihi, Osmanlıların tek taraflı ve Orta Çağ’n umumî uygulaması olan ad hoc diplomasi döneminden çift ve çok taraflı, son kertede sürekli diplomasi ve mukim elçilikler dönemine geçişi aksettiren elçilik misyonlarının tarihî sürecinde ${ }^{27}$ önemli, aynı zamanda etkilerinin günümüze kadar yansıması itibariyle de özel bir konuma sahiptir. Bu tarihin

21 Österreichisches Staatsarchiv (OeStA), Finanz- und Hofkammerarchiv (FHKA), Reichsakten, Fz. 307.6, vr. 8.

22 Peter Meienberger, Johann Rudolf Schmid zum Schwarzenhorn als kaiserlicher Resident in Konstantinopel in den Jahren 1629-43: Ein Beitrag zur Geschichte der diplomatischen Beziehungen zwischen Österreich und der Türkei in der ersten Hälfte des 17. Jahrhunderts (Bern: Herbert Lang/Frankfurt: Peter Lang 1973), s. 121.

23 OeStA, FHKA, Reichsakten, Fz. 307.6, vr. 28.

24 Klaus Müller, Das kaiserliche Gesandtschaftswesen im Jahrhundert nach dem Westfälischen Frieden (1648 - 1740), (Bonn: Röhrscheid, 1976), s. 127.

25 İstisnaî olarak 1719'da Pasarofça Antlaşması'nın teyidi için gönderilen İbrahim Paşa Viyana’ya 14 Ağustos'ta beraberinde 763 kişi ile varmışken (Johann Baptist Schönwetter, Ausführliche Beschreibung des Empfangs und Einzugs, welchen der Türkische Groß-Botschafter [...] Ibrahim Bassa [...] (Wien: Schönwetter, 1719), s. 33.), Damian Hugo von Virmont İstanbul'a yaklaşık 500 kişiyle ulaştı (Strohmeyer, "Die Theatralität”, s. 418).

26 Teply, “Türkische Gesandtschaften”, s. 14-19.

27 Yaygın literatürü aktaran bir çalışma için bkz. Behice Özlem Gökakın, “The Ottoman Empire and European International Society: a theoretical - historical analysis" (doktora tezi), Bilkent Üniversitesi, 2010. Burada bu süreci dile getirmek, malumun ilamından başka bir şey olmayacaktır. 
aydınlatılması için kaleme aldığı eserlerin değeri bugün dahi muhafaza olan, Osmanlı seyahatnâmelerini Avrupa'ya ilk tanıtan, ${ }^{28}$ birincil kaynaklara dayanarak yazılmış ilk büyük ve kapsamlı Osmanlı tarihini yazan Joseph von Hammer'in (1774-1856) aynı eserinde yer alan "Osmanlıların kuruluşundan Küçük Kaynarca Antlaşmasina kadar elli Avrupal, Asyalı ve Afrikalı devletin Bâbıâlîye ve Bâbrâlînin onlara yolladiğı elçiler listesi” ${ }^{29}$ Osmanlı tarihi kaleme almış tarihçilerin faydalandığı temel bir başvuru kaynağı olmuştur. Bu listede bulunan ve 1535-1748 yılları arasında Habsburglara gönderilen Osmanlı elçilerinin sıralaması ${ }^{30}$ OsmanlıHabsburg diplomatik tarihi açısından öncü bir nitelik taşır. Günümüze doğru gelindiğinde örneğin sefaretnâme neşirleri gerçekleştirmiş tarihçilerin katkıları ve burada zikredilmeyen belli başlı akademik çalışmalar, 1488'den Osmanlı-Habsburg askerî mücadelesini kesin olarak nihayete erdiren Ziştovi Antlaşması'na kadar Viyana’ya gönderilmişs sayısı seksen-doksan kadar olan Türk elçilerine ${ }^{31}$ dair malumatı genişletmiş olmakla önemli işleve sahiptir. Son kertede bu birikim, yerli ve yabancı geniş bir literatürde yerini almaktadır.

Osmanlılarla Habsburglar arasındaki diplomatik trafiğin başlamasıyla birlikte, Viyana’ya irsâl olunmuş ve kaynaklarda izlerine rastlanan başka Osmanlı temsilcileri de söz konusudur. Ancak bunlar Osmanlı payitahtından değil, diplomatik bakımdan yoğun faaliyette bulunmuş olan Budin beylerbeylerinin temsilcileridir. Bilhassa öne çıkan, 1686 yılına kadar Osmanlı hâkimiyetinde kalan Budin'den, eyaletin Viyana'yla neredeyse müstakil biçimde irtibat kuran beylerbeyleri tarafından genellikle az sayıda bir maiyetle görevlendirilmiş memurlardır. Gönderilişs sebepleri arasında beylerbeylerinin Saray Harp Şûrası başkanına (Hofkriegsratpräsident) yolladıkları mektupları iletmek ve görevine yeni başlamış bir beylerbeyinin bilgisini vermek bulunurdu. 1604-1616 yılları arasında Saray Harp Şûrası'na Budin Beylerbeyi Kadızâde Ali Paşa tarafından gönderilmiş 58 mektubun ulaşmış olması, ${ }^{32}$ diplomatik trafiğin hacmi hakkında fikir verir.

28 İlber Ortaylı, "Joseph Freiherr von Hammer-Purgstall”, TDV İslâm Ansiklopedisi (DİA), 1997, XV, 491-494.

29 Joseph von Hammer, Geschichte des Osmanischen Reiches (GOR), IX (Pest: C. A. Hartleben's Verlage, 1833), s. 115.

30 Hammer, GOR, IX, s. 329-330.

31 Teply, “Türkische Gesandtschaften”, s. 14. Aynı yerde, bu süre aralığında İstanbul'a yaklaşık 130 Habsburg elçisinin geldiği bilgisi verilir.

32 Gustav Bayerle, The Hungarian letters of Ali Pasha of Buda: 1604-1616, (Budapest: Akad, 1991), s. xiii. 
Mektupların içeriğinde esirlerin salıverilmesi, Habsburgların geciktirdikleri yıllık vergilerinin bir an önce gönderilmesi, sınır tespiti ${ }^{33}$ ve sıklıkla sınır ihlâlleriyle yağmalar hakkında şikâyet gibi konulara rastlanır. Burada ilginç bir husus, beylerbeylerin gönderdikleri -genellikle çavuş ve kâhya olan- bu memurların zaman zaman kayzerin huzuruna kabul edilmesinin istisnaî bir durum olmamasıdır. ${ }^{34}$ Nitekim babası III. Ferdinand'ın ölümü üzerine 1658'de kayzer unvanını alan I. Leopold'u sultan adına tebrik için 21 Mart 1659'da Budin Beylerbeyi Gürcü Kenan Paşa tarafindan gönderilen Ali Ağa gibi birçok elçi, kayzerin huzuruna kabul edilmişti. ${ }^{35}$

Hiç şüphesiz Avusturya ve Osmanlı devlet arşivleri ile yazma eser, kronik, havadis derlemeleri, günlük ve gazete gibi çağdaş kaynakların henüz kullanılmamış veya yeniden sorgulanıp değerlendirilecek malzemeleri ışı̆̆ında yapılacak yeni çalışmaların, Osmanlı-Habsburg diplomatik ilişkilerinin birçok veçhesine dair mevcut bilgilerin ikmaline olanak sunacağı açıktır. Sözgelimi Viyana’daki imparatorluk arşivini meydana getiren arşivlerden biri olan Hanedan, Saray ve Devlet Arşivi (Haus-, Hof-, und Staatsarchiv), konuya ilişkin zengin bir kaynak sağlar. ${ }^{36}$ Osmanlı İmparatorluğu ile ilgili başta siyasî olmak üzere çeşitli alanlara ait belgeler bulunduran Türkiye (Turcica) fonu ve elçilerin huzura kabullerine (Audienz) dair bilgilerin muhafaza edildiği teşrifat/protokol zabıtları (Zeremonialprotokolle / Protocollum Aulicum in Ceremonialibus) bu arşivde yer alır; teşrifata ilişkin kayıtlar 1652 yılından itibaren başlar. Bunlar, müsvedde hâldeki zabıtların temize çekilmiş suretleri olup yıllara göre sıralanmıştır ve ciltli hâldedir. Daha önceki yıllara ait bilgilere ulaşmak içinse 1562 yılından başlayan ve ayrı ayrı varaklar hâlindeki nüshalardan oluşan eski teşrifat zabıtları (Ältere Zeremonialakten) serisine müracaat etmek gerekir. Bu evrakta sefaretlerin Kutsal Roma Alman İmparatorluğu'nun sınırında karşılanmalarından itibaren izledikleri güzergâhtan Viyana'ya girişlerine kadarki sürece dair bilgiler de yer alır. Yanı sıra Habsburg

33 Géza Dávid, “Budin”, TDV İslâm Ansiklopedisi (DİA), 1992, VI, 348.

34 Teply, “Türkische Gesandtschaften”, s. 16. Örneğin Budin'den 1620'de gelen bir elçinin itimatnâme (Credentional) ulaştırmasının yanında sözlü olarak da bilgi verdiği, havadis derlemesinde dahi yer almaktadır, bkz. Martin Meyer, Theatrum Europaeum oder außführliche und warhafftige Beschreibung aller und jeder denkwürdiger Geschichten [...], I (Franckfurt am Mäyn: bey Daniel Siebet, 1662), s. 344.

35 OeStA, Haus-, Hof- und Staatsarchiv (HHStA), Ältere Zeremonialakten ( $̈ Z$ ZA) 6-22, vr. 29.

$36 \mathrm{Bu}$ makalede yer alan ekseri yabancı terim ve isimlerin bugüne kadar Türkçe karşılıkları bulunmamaktadır. Terminoloji ve tercümede tavsiyeleriyle katkıda bulunan değerli hocam Prof. Dr. Kemal Beydilli'ye müteşekkirim. 
sarayında teşrifattan sorumlu olmuş yüksek rütbeli memurların, ayrıca imparatorlukta önemli görevlerde bulunmuş ve neslinden birçok devlet ve din adamı çıarmış olan ünlü Avusturya-Bohemya ailesi Harrach gibi soylu ailelerin üyelerinin yazışmaları da orijinal kaynak değeri taşıması itibariyle zikredilmelidir. ${ }^{37}$ Sözü edilen birey ve aile evrakı aile arşivleri (Familienarchive) fonunda bulunur.

Hanedan, Saray ve Devlet Arşivi dışında Harp Arşivi (Kriegsarchiv), iki devletin ilişkiler tarihini aydınlatabilecek muazzam bir belge zenginliğine sahiptir. Aşağıda ele alınacak olan Saray Harp Şûrası (Hofkriegsrat), Osmanlı-Habsburg diplomatik ve siyasî tarihini şekillendiren en önemli kurumlardan birisi olması itibariyle kurumun ürettiği belgeler, bu tarihin araştırılması safhasında vazgeçilmez bir kaynaktır. Şûra ile irtibatlı tüm yazışmalar, Saray Harp Şûrası protokolleri (Hofkriegsrat Protokolle) adındaki defterlerde muhafaza edilmiştir. Arşivde, Şûra’nın kayıtlarını bulunduran üç ayrı fon olmakla birlikte Osmanlılarla ilişkileri ilgilendiren fon Viyana merkezlidir (Wiener Hofkriegsrat). Fondaki 1557-1848 yılları arasını ihtiva eden protokol defterleri yıllara göre düzenlenmiş olup kuruma ulaşmış belgeler yani gelen evrak (Expedit) ile kurum tarafından hazırlanmış belgeler yani giden evrak (Registratur) olmak üzere her yll için iki adet olarak bulunmaktadır. Defterler -birkaç istisna yıl haricinde-alfabetik bir dizine (Index) de sahiptir. Bu sayede Şûra, bir kişi ve kurumla ilgili yazışma geçmişini ve süreç takibini XVI. yüzyılın ikinci yarısı gibi erken bir tarihten itibaren zahmetsizce ve süratle yapabilmiştir; aynı kolaylık, günümüz araştırmacıları için de geçerlidir. Elbette Harp Arşivi'nin asıl önemi, harp tarihine ilişkin ana kaynak oluşudur. Bu arşivde yer alan ve Kutsal Roma Alman İmparatorluğu'nun 1323-1882 yılları arasındaki savaş tarihine ait belgelerden oluşan eski sefer evrakı (Alte Feldakten) isimli fon, yaklaşık iki buçuk asır süren Osmanlı-Habsburg askerî mücadelesine de ışık tutmak vasfını haizdir.

Bundan başka Maliye Dairesi Arşivi (Finanz- und Hofkammerarchiv) de zikredilmelidir. Zira İstanbul'a gelen yabancı elçilerin imparatorluk topraklarına girmeleriyle birlikte masraflarının, uygulamanın kaldırılacağı 1794 yazına kadar $t a-$ yinat adıyla Osmanlılar tarafından karşılanmış olması keyfiyeti ${ }^{38}$ gibi Habsburglar

$37 \mathrm{Bu}$ konuda kapsamlı bir çalışma yakın zamanda yayımlandı, bkz. Michael Hochedlinger, Verzeichnis der Familienarchive und persönlichen Schriftennachlässe zur österreichischen Geschichte: 1500-2000, (Wien [u.a.]: Böhlau, 2018).

38 Mübahat S. Kütükoğlu, "XVIII. Yüzyılda Osmanlı Devleti'nde Fevkalâde Elçilerin Ağırlanması”, Türk Kültürü Araştırmaları, XXVII/1-2 (1989), s. 199-230. 
da yabancı misafirlerinin masraflarını karşıladı (Kostfreihaltung). ${ }^{39}$ Maliye Dairesi hizmetine giren yeni memurlar için hazırlanmış 1658 yılına ait bir kurum içi el kitabının 46. maddesinde, Türk elçilerine günlük 100-150 Taler (Reichsthaler) verildiği ve bu miktardan, İstanbul'daki elçilerin ihtiyaçları göz önünde bulunularak aşağıya inilmemesi gerektiği bildirilir. ${ }^{40}$ Dolayısıyla sözü edilen karşılıklı uygulamada ödeme miktarının yine mütekabiliyet esasına göre belirlendiği açıktır. Maliye Dairesi Arşivi, masrafların kayıt olunduğu evrakı muhafaza eder. Bu evrakta elçiliklerin ihtiyaçları ve talepleri doğrultusunda oluşan masraf kalemleri detaylı bir biçimde yazılıdır. Ayrıca elçilik heyetlerine dair unvan/rütbe, heyet mevcudu, konaklama yeri ve süresi gibi değerli başka bilgiler de bulunabilir.

Osmanlı elçilik heyetlerinin izlerine Viyana'da mukim bilhassa Venedik, İspanya ve Fransa elçilerinin Hanedan, Saray ve Devlet Arşivi'nde muhafaza edilen raporlarında rastlamak mümkündür. Bu raporlar, Osmanlı elçilerinin Viyana’daki faaliyetlerini izlemeyi sağlayan dışarıdan bir gözlem olması hasebiyle önemlidir. Örnek olarak Venedik Cumhuriyeti mukim elçilerine ait Almanya raporları (Dispacci di Germania) fonundaki 1541-1788 yılları arasını kapsayan evrak verilebilir. Binâenaleyh Avusturya Devlet Arşivleri, Osmanlı-Habsburg ilişkileri bağlamında başta Almanca olmak üzere Latince, Fransızca, İtalyanca ve Macarca dillerindeki yazma nüshalar hâlinde değerlendirilmeyi bekleyen sayısız vesikaya sahiptir. Bu makalede, şimdiye kadar ortaya konmuş veriler yukarıda zikredilen kaynakların bir kısmı kullanılmak suretiyle elde edilen yeni bulgularla birleştirilerek, Osmanlı sefaretlerini merkeze alarak Osmanlı-Habsburg diplomasi tarihine dair bir inceleme yapılmaya çalışılmıştır.

\section{Osmanlılarla Diplomatik İlişkiler Özelinde Kayzerî Makamlara Genel Bir Bakış}

Habsburglara gönderilmiş Osmanlı elçilikleri bahsinde Türkçe literatürde üzerinde durulmamış bir husus, Kutsal Roma Alman İmparatorluğu payitahtında bulunmuş Osmanlı misafirlerin ağırlanma sürecinin ilgili kayzerî makamlarca

39 Elçiliklerin masraflarının tamamının veya bir kısmının ev sahibi tarafından karşılanması keyfiyeti Osmanlılarla Habsburglar arasındaki diplomatik münasebette XVIII. yüzyıla kadar sürse de, Avrupa diplomasisinde de yaygın olan bu uygulama XVII. yüzyılın ilk yarısına gelindiğinde çoğu Avrupa devletinde istisna düzeyine inmişti, bkz. Müller, Das kaiserliche Gesandtschaftswesen, s. 163.

40 Hansdieter Körbl, Die Hofkammer und ihr ungetreuer Präsident: eine Finanzbehörde zur Zeit Leopolds I., (Wien: Böhlau, 2009), s. 383-384. 
yürütülmüş idarî boyutudur. Bu hususta Almanca literatürün de zengin olduğu söylenemez. Literatür taraması neticesinde, çok sayıdaki çalışmanın odağının Osmanlı payitahtına gönderilmiş Habsburg elçilerine yönelik olduğu görülmektedir. Hatta bunlarda da, şümullü bir anlatım için elzem olan Osmanlı kurumlarının ürettiği belgelerin yeterince kullanılmadığı ve idarî işleyişin yetkin bir şekilde ele alınmadığı açıktır. Bunun başlıca nedeninin dil engeline takılmadan kaynaklandığı öne sürülebilir.

Üzerinde durduğumuz noktaya dönecek olursak, doğrudan Osmanlı sefaretleri bağlamında Habsburg idarî boyutunu ele alma amacı taşımasa da buna ilişkin bilgi aktaran Karl Teply'nin 1976 ve Richard Perger ile Ernst Dieter Petritsch'in 1999 yılında kaleme aldıkları makalelerinin, ${ }^{41}$ hâlâ en kapsamlı çalışmalar olmaları dikkat çekicidir. ${ }^{42}$ Bunun haricinde Osmanlı sefaretlerine ilişkin bilgiler, daha ziyade Viyana’da bulunmuş yabancı elçileri konu edinen çeşitli tez, makale ve akademik kitapta dağınık hâlde bulunur ve birkaç satırla sınırlıdır. ${ }^{43}$ Elbette bu satırlarda, Osmanlı elçilik heyetlerinden hangi kurumların ve kimlerin ne derecede ve hangi konularda sorumlu oldukları gibi çözüme muhtaç temel meselelere ilişkin ancak sınırlı cevaplar bulabilmek mümkündür. Dolayısıyla bugüne değin ortaya konmuş tüm bulgular bir araya getirildiği takdirde bile, sağlıklı ve net bir resmin oluşmadığı gözlemlenmektedir. Oysa bu boyutun göz ardı edilmesinin, mezkûr konunun bilinmeyenlerini tatmin edecek ölçüde aydınlatacak yeni ve derinlemesine araştırmalara dayanak oluşturacak kaynakları ve belgeleri kullanabilmek

41 Teply, “Türkische Gesandtschaften”; Richard Perger ve Ernst D. Petritsch: "Der Gasthof "Zum Goldenen Lamm” in der Leopoldstadt und seine türkischen Gäste”, Studien zur Wiener Geschichte, 55 (1999), s. 147-172.

42 Petritsch, söz konusu makaleyi genişleterek Viyana’ya gelen Osmanlı büyükelçilik heyetleri hakkında yakın zamanda çıkan yeni bir makale hazırlamışır, bkz. Ernst D. Petritsch: "Türken in der Wiener Vorstadt: Osmanische Großbotschaften nach Wien im 18. Jahrhundert," Die Türkenkriege des 18. Jahrhunderts: Wahrnehmen - Wissen - Erinnern, hg. von Wolfgang Zimmermann, Josef Wolf (Regensburg: Schnell \& Steiner, 2017), s. 101-128.

43 Birkaç örnek vermek gerekirse: Irmgard Pangerl, Martin Scheutz, Thomas Winkelbauer (Hg.): Der Wiener Hof im Spiegel der Zeremonialprotokolle (1652-1800): eine Annäherung, (Innsbruck [u.a.]: StudienVerlag, 2007); Franz-Stefan Seitschek, “"Einige caeremonialpuncten bet(reffend)": kommunizierende Gefäße: Zeremonialprotokoll und Wiener Diarium als Quelle für den Wiener Hof (18. Jh.)” (yüksek lisans tezi), Wien, Universität Wien, 2011; Eveline Markom: "Die Diplomatischen Beziehungen Österreichs zum Osmanischen Reich im 18. Jahrhundert: unter besonderer Berücksichtigung der Orientalischen Akademie in Wien", (Diplomarbeit) Wien, Universität Wien 2001. 
önünde önemli bir engel olduğu söylenebilir. Zira diplomasi alanında sorulabilecek birçok sorunun cevabı, karar verme organlarını, idarî yapılarını, işleyişlerini ve aktörlerini, özetle idarî tarihi (Verwaltungsgeschichte) ${ }^{44}$ tanımaya bağlıdır.

Osmanlı sefaretlerini ilgilendiren XVII.-XVIII. yüzyıllar arasındaki Avusturya Devlet Arşivleri belgeleri incelendiğinde, imparatorluğun gereği olarak bir teâmüle sahip olunduğu göze çarpmaktadır. Bu teâmül sefaretlerin Viyana’ya doğru gelişlerinden İstanbul'a dönüşlerine kadar, yani serhadde karşılanmaları, şehre girişleri, ikametgâha yerleştirilmeleri, kayzerî yetkililerle haberleşmeleri, huzura kabulleri, masraflarının karşılanmaları, çeşitli merasimlere davet edilmeleri gibi hemen her safhayı kapsar. Habsburglar bu teâmülü sağlıklı bir biçimde sürdürebilmek ve ihtiyaçlar doğrultusunda geliştirip dönüştürebilmek için geçmiş muamelata sıkça başvurmuş, uygulamalarda tutarlılığa önem vermiştir. Ayrıca Zitvatorok sonrasında üzerinde dikkatle durdukları Osmanlılarla diplomatik "mütekabiliyet ve eşitlik" gereği, Habsburg elçilerinin kayıt altına alıp merkeze bildirdikleri raporlarda yer alan Osmanlılardan ne şekilde muamele gördükleri bahsi de kıyas unsuru olarak kullanılmış ve aldıkları kararlarda rol oynamıştır. Netice itibariyle diplomatik hafızayı canlı tutmayı sağlayan belgeler kurumlarca muhafaza edilip kaideler buna göre belirlendiğinden, öncelikle Habsburg merkez teşkilâtının ilgili kurumları ve bu kurumların işleyişleri ana hatlarıyla da olsa ortaya konmaya çalışılacaktır. ${ }^{45}$

44 Habsburg idarî tarihini konu edinen çalışmalar XIX. yüzyıla uzanır. Öncü eserler Hermann Ignaz Bidermann (1867/89) ve Eduard Rosenthal (1887) tarafından kaleme alınmıştır. Genel kabule göre sahanın en temel eseri, Thomas Fellner’in yazdığı ve ölümünün ardından Heinrich Kretschmayr tarafından tamamlanıp 1907'de yayımlanan 3 ciltlik "Die österreichische Zentralverwaltung: Von Maximilian I. bis zur Vereinigung der österreichischen und böhmischen Hofkanzlei (1749)" isimli eserdir. Yine 3 cilt hâlindeki devamı Friedrich Walter tarafından 1938-1956 yılları arasında yayımlanmısstır: "Die österreichische Zentralverwaltung: Vereinigung der österreichischen und böhmischen Hofkanzlei bis zur Einrichtung der Ministerialverfassung (1749-1848)”. Bununla birlikte 2000'li yıllardan sonra idarî tarih çalışmaları tekrar canlanmış ve çok sayıda kitap basılmıştır. Bu makale için kullanılan kaynaklardan biri, 3 cilt hâlinde yayımlanacak olan "Verwaltungsgeschichte der Habsburgermonarchie in der Frühen Neuzeit" isimli eserin Haziran 2019'da yayımlanmış "Hof und Dynastie, Kaiser und Reich, Zentralverwaltungen, Kriegswesen und landesfürstliches Finanzwesen, (Wien: Böhlau, 2019)” isimli ilk cildidir. Hazırlığı birkaç yıldır süren bu kıymetli çalışmayı hazırlayanlar arasında bulunan Prof. Dr. Thomas Winkelbauer, eseri henüz yayımlanmadan istifademe sunma lütfunda bulunmuştur.

45 Elbette buradaki çaba ancak kabaca bir tarif sayılabilir ve teşkilât tarihi gibi hacimli bir konu için yetersiz kalacaktır. Şimdiye dek Avrupalı tarihçiler eliyle yapılmış çalışmalara bakıldığında, 
Kayzer I. Maximilian'ın (1493-1519) imparatorluğun idarî yapılanmasında gerçekleştirdiği reformlar (Regimentsordnung) 1502 yilında herseklerin muhalefetiyle karşılaşsa da merkezî Habsburg Devleti'nin kurulması için ilk adım atılmış oldu. Reformları takip eden Arşidük Ferdinand'ın (Mart 1558'de I. Ferdinand ismiyle kayzer) ağabeyi V. Karl'ın (1519-1556) vekili olarak imparatorluğu, Macaristan ve Bohemya krallıklarını ve mevrus mülkleri (Erblande) başkent Viyana’dan daha iyi yönetebilmek için imzaladığ 1 Ocak 1527 tarihli imparatorluk nizamnâmesi (Hofstaatsordnung), Habsburg merkez teşkilâtının doğum tarihi kabul edilir. ${ }^{46} \mathrm{Bu}$ çerçevede kendi inisiyatifiyle Hofrat (Saray Şûrası, 1559'de Reichshofrat), Geheimer Rat (Müşavir-i Has), Hofkanzlei (Saray Başvekâlet Dairesi, 1559 'da Reichshofkanzlei) ve Hofkammer (Maliye Dairesi) isimli kurumlar yeni bir düzenlemeyle ihdas edildi. Bu idarî organlar 1848'e kadar işlevini sürdürdü. ${ }^{47} \mathrm{Sa}-$ ray Şûrası, eskiden her Avusturya ülkesinde ayrı ayrı olan "şûraları" cem etmiş, devletin merkezîleşmesi ve kuvvetli bir monarşi olması yolunda mühim bir adım atılmıştı. Bu kurum imparatorluğun en yüksek idarî organı ve mahkemesiydi, aynı zamanda borçlar konusunda sorumluydu. Osmanlılarla ilişkiler bakımından önemi, XVII. yüzyılın başlarına kadar diplomatik trafiğin ilk muhatabı olmasıdır. ${ }^{48}$

Müşavir-i Has, müstakil olarak karar verme yetkisine sahip olmasa da XVII. yüzyılın ortalarına kadar imparatorluğun iç ve dış siyasetinin belirlenmesinde önemli rol oynayıp imparatorluk meselelerinde son sözü söyleyecek olan kayzerin hükmü üzerinde etkin en yüksek danışma kuruluydu. Kayzerin ihtiyaç duymasına bağlı olarak tertiplenen Müşavir-i Has toplantılarında az sayıda devlet adamı

konunun makale formatının sınırlarının bir hayli ötesine, çok sayıda akademik kitap ve teze malzeme çıkaracak zenginlikte olduğu görülür. Belki Türkiye'de bu külfetli işe, hâlihazırda yazılmış ve başvuru eserleri olarak kabul gören neşriyatın çevirileriyle başlanabilir.

46 Thomas Fellner, "Zur Geschichte der österreichischen Centralverwaltung (1493-1848) I. Bis zur Errichtung der österreichischen Hofkanzlei”, Mitteilungen des Instituts für Österreichische Geschichtsforschung, 8 (1887), s. 258-277.

47 Thomas Fellner ve Heinrich Kretschmayr, Die österreichische Zentralverwaltung (ÖZV), I. Abt.: Von Maximilian I. bis zur Vereinigung der österreichischen und böhmischen Hofkanzlei (1749), c. I, (Wien: Adolf Holzhausen, 1907), s. 33.

48 Saray Başvekâlet Dairesi (Reichshofkanzlei) Osmanlılarla diplomatik ilişkilerden sorumlu olma vasfını 1615'te nihaî olarak Saray Harp Şûrası'na (Hofkriegsrat) devretti. Başvekâlet Dairesi'nden Gerhard Questenberg 1607'de Saray Harp Şûrası hizmetine girdiğinde artık Türk meselelerine ait tüm eski evrak Şûra’ya nakledildi, bkz. Lothar Groß, "Die Geschichte der Deutschen Reichshofkanzlei von 1559 bis 1806, (Wien: Selbstverlag des Haus-, Hof- u. Staatsarchivs, 1933), s. 38 dipnot 121. 
bulunurdu ki bunlar imparatorluk sarayının en kıdemli ve kayzere yakın olan -Obersthofmeister, Obersthofmarschall ${ }^{49}$ ve Reichsvizekanzler (İmparatorluk şansölyesi vekili) gibi- hizmetkârlarıydı. Bu toplantılarda örneğin Başvekâlet Dairesi'ne ulaşan elçilik raporları mütâlaa edilir ve devletin siyasetine yön verilirdi.

Maliye Dairesi ilk defa 13 Şubat 1498'de, Alman İmparatorluğu'nun ve Habsburglu mevrus mülklerin malî durumunu sağlıklı bir surette görmek ihtiyacını karşılamak amacıyla kurulmuştu. Kayzer dâhil herkesin hazineye masrafı kayıt altına alınacaktı. Mevrus mülklerin giderleri de artık sadece hazinedarbaş1 (oberster Schatzmeister) üzerinden sağlanacaktı. Maliye Dairesi tüm kurumlar içerisinde geçmişi en eski ve nizamnâme (Instruktion) sayısı en fazla olan kurumlardan biriydi. Önem sırasına göre hazine tarafından karşılanması gereken masraflar başlıca şunlardı: Sarayın ihtiyaçları ve personel maaşları, askerî giderler, imparatorluk topraklarındaki harcamalar ve devletin tüzel kişilere borçlarından sonra diplomatik masraflar (giden ve gelen, ayrıca saraya gelmiş yabancı elçilerin ihtiyaçlarının karşılanması). ${ }^{50}$

1556 'da tahttan ferâgat eden ağabeyinin yerine hükümdar olduktan kısa bir müddet sonra aynı yılın 17 Kasım'ında, Osmanlıların Orta Avrupa'daki askerî ilerleyişi neticesinde "daimî" bir harp danışma kurulu ihtiyacını karşılamak için Viyana’da I. Ferdinand'ın isteğiyle kurulan ve başta tüm imparatorluğun askerî açıdan sorumlusu olan Saray Harp Şûrası (Hofkriegsrat), teşkilâtlanmanın ikinci ve en önemli gelişmesidir. ${ }^{51}$ Saray Harp Şûrası Habsburgların askerî ilişkilerde strateji belirleyen en yüksek organı oldu ve bu özelliğini Rusya için 1720, Os-

49 Fellner ve Kretschmayr, ÖZV, s. 45-48. Obersthofmeister Viyana sarayının (Hofburg) en kıdemli memuruydu. Geniş sorumluluğa, buna bağlı olarak yetkilere sahipti. Kayzerin yokluğunda Müşavir-i Has toplantılarda vekil olarak bulunurdu. Nizamnâmede en yüksek başkan ve bakan (obrist president und canzler) şeklinde nitelenir. Obersthofmeister, Hammer'e göre Osmanlı sarayındaki bâbüssaâde/kızlar ağasına, Obersthofmarschall ise çavuşbaşına karşılık gelir, bkz. Joseph von Hammer, Des osmanischen Reichs Staatsverfassung und Staatsverwaltung, dargestellt aus den Quellen seiner Grundgesetze: 2 Die Staatsverwaltung, (Wien, Camesina, 1815), s. 11, 119.

50 Körbl, Die Hofkammer, s. 34, 44-45.

51 Thomas Winkelbauer, Österreichische Geschichte 1522-1699. Ständefreiheit und Fürstenmacht: Länder und Untertanen des Hauses Habsburg im konfessionellen Zeitalter, c. I, hg. von Herwig Wolfram, (Wien: Carl Ueberreuter, 2003), s. 33-41. Habsburglar açısından sancılı geçen Otuz Yıl Savaşı sırasında Şûra’nın iş yükünü hafifletmesi için 1640'lı yıllarda Genel Harp Komiserler Şûrası (Generalkriegskommissariat) göreve getirilip barış zamanında da varlığını sürdürmesi yönünde karar alındı (1650). Bu durum imparatorluğun askerî 
manlılar içinse 1753 yılına dek sürdürdü. ${ }^{52}$ Habsburgların dış siyasetinin belirleyici organlarından olan Saray Harp Şûrası, XVII. yüzyılın ilk çeyreğinden itibaren İmparatorluk Başvekâlet Dairesi'nden (Reichshofkanzlei) kendisine devrolunan Osmanlılarla diplomatik ilişkilerden, Türklere karşı tüm sınır muhafazası

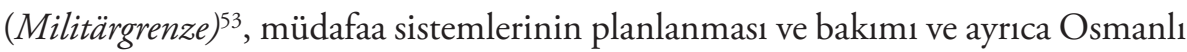
payitahtındaki temaslar gibi hususlarından sorumluydu. 1547 Antlaşması sonrasında ilk defa Johann Maria Malvezzi'nin İstanbul'da mukim olarak bulunmaya başlamasının ardından Habsburg elçileri/kapı kethüdaları, misyonlarının gereği olarak başta Osmanlılar ve diğer devletler hakkında bilgiler aktaran genellikle haftalık ve görevlerinin sonunda kaleme aldıkları ayrıntılı nihaî raporlarını (Finalrelation $^{54}$ XVII. yüzyıldan itibaren Saray Harp Şûrası'na gönderir, emir ve talimatları yine Şûra'dan alırlardı. ${ }^{55}$ Şûra daha sonra bilgi aktarımını Saray ve Devlet Başvekâlet Dairesi'ne (Hof- und Staatzkanzlei) yapıyordu. ${ }^{56}$ Şûra'nın başkanı (Hofkriegsratpräsident), kayzere faaliyet raporunun sunumunu yapardı. Saray Harp Şûrası'nın kendi bütçesi yoktu, imparatorluğun en yüksek malî kurumu olan Maliye Dairesi'ne bağlıydı ve ihtiyaçları maliye tarafından karşılanıyordu. ${ }^{57}$

idaresinde şûralar arasında görev paylaşımı yapılmasına yol açtı (Fellner ve Kretschmayr, ÖZV, s. 256-257).

521753 'te yerini, aydınlanmış mutlakıyetin oluşturulmasının baş mimarı, devlet şansölyesi, Devlet Şûrası'nın (Staatsrat) kurucusu ve özellikle dış işlerden sorumlu Wenzel Anton von Kaunitz-Rietberg'in (1753-1792) göreve getirilmesiyle birlikte Devlet Başvekâlet Dairesi'ne (Staatskanzlei) bırakmıştır, bkz. Fellner ve Kretschmayr, ÖZV, s. 240.

53 Bu konu için bkz. Gunther E. Rothenberg, The Austrian Military Border in Croatia, 15221747, (Urbana: The University of Illinois Press, 1960) ve Ömer Gezer, “1522'den 19. Yüzyıla Kadar Habsburg Mutlakıyetinin İnşası ve Militärgrenze”, Avrupa Tarihinde Türk Eli Doç. Dr. Gümeç Karamuk Armăganı, haz. Ramazan Acun, Serhat Küçük, (Ankara: Hacettepe Üniversitesi Yayınları, 2017), s. 137-157.

$54 \mathrm{Bu}$ raporlar diplomatik, siyasî ve sosyal tarih açısından değerli başlıca kaynaklar sınıfinda yer alır. Bir örnek için bkz. Hüseyin Onur Ercan, "Osmanlı-Habsburg Diplomasisi: Rudolf Schmid'in Nihâ̂ Raporunun Türkçeye Çevirisi ve Otuz Yıl Savaşlarıyla İlişkisi (16291643)” (yüksek lisans tezi), İstanbul Üniversitesi, 2013.

55 Yukarıda ifade edildiği üzere yazışmalar başta Başvekâlet Dairesi üzerinden sağlanıyordu. Harp Şûrası'nın kurulmasından sonra, örneğin 1561-1569 yılları arası incelendiğinde, Başvekâlet Dairesi'ne gelen raporların büyük oranda Müşavir-i Has toplantılarında ele alındığı görülür (Groß, Die Geschichte der Deutschen Reichshofkanzlei, s. 156).

56 Teply, “Türkische Gesandtschaften”, s. 76.

57150 Florin’i aşmayan masraflar Harp Maliye Dairesi'nden (Kriegszahlmeisteramt) tahsil edebilirdi. Bu meblağın üstü Maliye Dairesi'ne bildirilmek suretiyle kayzerin onayına muhtaçtı (Fellner ve Kretschmayr, ÖZV, s. 238-239). 
Bu durum, yukarıda sözü edilen Maliye Dairesi Arşivi'nde bulunan belgelerin menşeini açıklamaktadır.

\section{Karşılanma, Ağırlanma, İletişim ve Teşrifat}

Osmanlı elçilik heyetlerinin karşılanması ve ağırlanmasının idarî boyutuna dair şimdiye kadar ikincil literatürde fazla kalem oynatılmamış olması gerçeği, tahminlerden veya genellemelerden siyrilıp bu hususta merak edilenlere dair cevapların üstündeki gizem bulutunu dağıtmak için arşiv belgelerinin söyleyeceklerine kulak vermekten başka çare bırakmamaktadır. Saray Harp Şûrası protokollerinin yanında Hazine ve Maliye Dairesi arşivindeki (Finanz- und Hofkammerarchiv) belgelere bakıldığında, arşivin konuya ilişkin yeni bulgulara imkân tanıyan başat kaynak olduğu gözlenir. Çünkü mezkûr arşivde bulunan Saray Harp Şûrası ile Maliye Dairesi arasındaki kimi yazışmalar, gerek içeriği gerekse gönderen/alıcı bilgileriyle idarî boyutu başka bir kaynağın sağlayamayacağı şekilde gözler önüne sermektedir. Buna göre, XVII.-XVIII. yüzyıllar arasındaki dönem için geçerli olduğu görülen mutat (gebreuchig) uygulamayı şu şekilde tarif etmek mümkündür. ${ }^{58}$

Osmanlı elçilik heyetleri Balkanlardaki orta kol (Via Militaris) güzergâhı olan Edirne, Filibe, Sofya, Niş ve Belgrad üzerinden Budin'e devam edip serhadde ulaştığında, Habsburg sınır garnizonu komutanı bunu Viyana'ya (genellikle Saray Harp Şûrası'na) bildirir, müteakiben Maliye Dairesi, elçilik heyetine Habsburg topraklarından başkente kadar refâkat edecek bir komiseri (Spesirungscommissär) görevlendirirdi ${ }^{59}$. Eğer bu heyet barış antlaşmaları vesilesiyle teati edilecek bir büyükelçilik heyetiyse, elçiliklerin denk zamanda mübadele yerine ulaşmış olmalarını

58 Malumdur ki arşiv belgelerini okumanın yanında onları yorumlayabilme olmaksızın doğru çıkarımda bulunulamaz. Bu konuda yardımlarına müracaat ettiğim, Hanedan, Saray ve Devlet Arşivi'nde geçirilmiş uzun yılların tecrübesinin getirdiği vukufiyetle mücehhez Dr. Ernst D. Petritsch'e, kıymetli katkılarından ötürü teşekkürü bir borç bilirim.

59 Silahdâr İbrahim Paşa’nın elçiliğini konu alan sefaretnâmede komiser şu şekilde tarif olunur: "...komisar tayin oldu komisar dimek zâhire verici dimektir..." (Friedrich von Kraelitz-Greifenhorst, "Bericht über den Zug des Groß-Botschafters Ibrahim Pascha nach Wien im Jahr 1719”, Sitzungsberichte der philosophisch-historischen Klasse der kaiserlichen Akademie der Wissenschaften in Wien, 158/III (1908), s. 24); Kara Mehmed Paşa'nın elçilik takririnde ise "...harc-ı râh vesâir mékûlât tedâriki içün Çâsâr tarafında kamûsarları ki defterdârlarıdur..." (Yücel, "Cevâhirü't-Tevârîh", s. 300). Günümüzde kullanılmayan Almanca "Spesi(e)rung” kelimesi, "Spesen” (masraflar) çoğul isminden türetilmiştir. Osmanlılarda bu iş için bir "mihmandar" tayin edilirdi, Kütükoğlu, "XVIII. Yüzyılda Osmanlı”, s. 199. 
sağlamak için henüz yola çıkılmadan Viyana’yla muhabere edilip bir tarih belirlenirdi. Aynı durum elçiliklerin dönüşleri için de söz konusuydu. İster büyükelçilik, ister 1640'da İstanbul'dan 18 kişilik heyetiyle gönderilen Müteferrika Handan Ağazâde gibi ortaelçilik ${ }^{60}$ (Internuntius) isterse Ahmed Çavuş ve beraberindeki 6 kişiden oluşan küçük bir elçilik heyeti örneğindeki gibi olsun, ${ }^{61}$ tüm elçiliklere bir komiser atanırdı. Bu komiser, Osmanlı elçilik heyetinin Habsburg topraklarına ulaşmasından itibaren ayrılmasına kadar, elçilikten sorumlu bir numaralı kişi olurdu ve elçiliğin geri dönmesiyle birlikte görevi sona erdiğinde, maliyedeki asıl memuriyetine (Hofkammerdiener) devam ederdi. Osmanlıların ağırlanması sürecinde sefaret heyetiyle uzun süre yakın temasta bulunan komiserin ev sahibine yakışır bir nezakette olması beklenirdi. Aksi ve kötü muamelede bulunmaları karşısında Osmanlılar durumu şikâyet edebilirdi. Nitekim 1636 yılında Budin Beylerbeyi Nasuhpaşazâde Vezir Hüseyin Paşa ${ }^{62}$ tarafından yollanan Müteferrika Ahmed Ağa ${ }^{63}$ Nisan ayının sonunda ${ }^{64}$ Viyanàya vardığında komiserin yol boyunca kötü muamelesine maruz kaldığını Saray Harp Şûrası'na bildirmişti. Bunun üzerine Şûra, Maliye Dairesi'ne yolladığı 8 Mayıs tarihli bir resmî yazıyla şikâyeti nakletti (Ek VIII). Resmî yazıda Ahmed Ağa'nın beylerbeyinin bilhassa çok kıymet verdiği bir ağa olduğu, eğer şikâyete neden olan durumlar giderilmezse işin büyüyüp kötü sonuçlar doğurabileceği, bu nedenle ağanın memnun ayrılmasının sağlanması gerekliliği bilgileri yer alır. ${ }^{65}$ Maliye Dairesi Arşivi'nde ileri tarihlerde benzer bir yazıya denk gelinmediğinden, meselenin çözülmüş olduğu varsayılabilir. Maliye Dairesi’nin kurum personel hiyerarşisine bakıldığında, komiserliğe atanan kişinin orta sıralarda yer alan bir memur olduğu görülmektedir. ${ }^{66} \mathrm{Bu}-$ nunla birlikte seçilen memurların biyografik bilgilerine dayanarak denilebilir ki bunlar dairede yıllardır çalışan ve tecrübeli kişilerdi. ${ }^{67}$ Viyana’dan gelen komiser ve tercümanın da katılımıyla Habsburg askerlerinin koruma ve eşlik sağladığı sefaret, başkente doğru yine menzillerde konaklayarak ilerlerdi.

60 OeStA, FHKA, Reichsakten, Fz. 303.29, vr. 8.

61 OeStA, FHKA, Reichsakten, Fz. 277.38, vr. 278.

62 Anton Gévay, A' budai pasak, (Bécsben: Strauss Antal, 1841), s 32.

63 Hammer, GOR, V, s. 222.

64 Meyer, Theatrum Europaeum, III (1670), s.165.

65 OeStA, FHKA, Reichsakten, Fz. 303.5, vr. 1.

66 Körbl, Die Hofkammer, s. 120, 125.

67 Örneğin Lorenz von Churelitz/Chureliz (1665), Carl von Damian (1676), Heinrich Freiherr von Penkler (1731). 
Osmanlı elçilerinin Viyana'daki ikametleri boyunca yerel yetkililerle kurdukları iletişim, üzerinde durulması icap eden bir diğer konudur. İletişimi sağlayan aracılar, tercümanlar olmuştur. Aynı durum İstanbul'a gönderilen Habsburg elçileri için de söz konusuydu. Zira bilindiği üzere kayzerî elçiler içinde Osmanlılara esir düşüp uzun yıllar İstanbul'da bir seçkinin kölesi iken Türkçeyi hem yazılı hem sözlü olarak mükemmel şekilde öğrenmiş olan Rudolf Schmid ${ }^{68}$ dışında, XVIII. yüzyılın ikinci yarısına kadar Türkçe bilen elçi yoktu. Viyana sarayında tercümanlığın şu diller için kullanıldığı görülür: İngilizce, Türkçe/Şark dilleri, Rusça/Lehçe, İspanyolca, İsveççe ve Macarca. Sarayda şark dilleri için ilk tercüman 1541'de görev almıştı (Johann Gaudier). Habsburglar hem prestije hem güvenilir hizmetlilere olan ihtiyacı karşılamak için dil oğlanları yetiştirmeye başladı. ${ }^{69} \mathrm{Bu}$ amaçla 1578 'den beri 10-17 yaş aralığında dil oğlanları (Sprachknaben) Türk dilini ve kültürünü öğrenmeleri için İstanbul'a yollandı. Birlikte gittikleri Habsburg elçisinin himâyesinde kaldıktan sonra tercüman olarak Viyana sarayında ve Habsburgların Osmanlı sınırında görev yaparlardı. Daha sonra 1650'de dil oğlanları için İstanbul'da bir enstitü kuruldu (Sprachknaben-Institut) ve onlardan oradaki mukim elçi sorumluydu. ${ }^{70}$ Dil oğlanları -diğer dillerde olduğundan farklı biçimde- 1664 savaşı nedeniyle kurulmuş olan İmparatorluk Harp Şûrası'na (Reichskriegshofrat) bağlıdı. Osmanlı İmparatorluğu’yla yapılan yazışmalarda tercümanlık faaliyetinde bulunmak başta olmak üzere fevkalâde elçilere eşlik ettiler ve öğrendikleri Türkçeyi Viyana’dayken yeni dil oğlanlarına öğretmekle de sorumluydular. Bu uygulama henüz XVII. yüzyılın ortalarına doğru şark dillerinden sorumlu saray tercümanlığı dairesinin (Hofdolmetscheramt) ihdasına ön ayak oldu. $^{71}$

68 İstanbul'da 1629-1643 yılları arasında mukim elçi, bkz. Meienberger, Johann Rudolf Schmid, s. 98 vd., Ercan, "Osmanl1-Habsburg Diplomasisi”, s. 60-66.

69 Clara Reiter, “ ... wo der Dollmetsch allzeit interpretirt”. Das Hofdolmetscheramt am Wiener Hof: Vom Karrieresprungbrett zum Abstellgleis", Lebende Sprachen, 58/1 (2013), s. 198, 204. Ayrica bkz. Ernst Dieter Petritsch, "Die Wiener Turkologie vom 16. bis zum 18. Jahrhundert”, Germano-Turcica: zur Geschichte des Türkisch-Lernens in den deutschsprachigen Ländern; Ausstellung des Lehrstuhls für Türkische Sprache, Geschichte und Kultur der Universität Bamberg, (Auss. u. Katalog) Klaus Kreiser, (Bamberg: Universitätsbibliothek Bamberg, 1987), s. 25-40.

70 Cécile Balbous, Das Sprachknaben-Institut der Habsburgermonarchie in Konstantinopel, (Berlin: Frank \& Timme, 2014), s. 53, 64.

71 Clara Reiter, "Vermittler zwichen West und Ost: Hofdolmetscher am Habsburger Hof (1650-1800), Politische Kommunikation zwischen Imperien: der diplomatische Aktionsraum 
Dil oğlanları dışında Osmanlı elçilik heyetleri bahsi için söz konusu olan en önemli memur, görevine kayzer tarafından atanan ve devletine karşı "mutlak sadâkat" vasfı taşıyan saray tercümanıydı (Hofdolmetsch). 1675 yılından itibaren şark dillerinde saray tercümanlığına getirilmiş herkes, öncesinde İstanbul'da bulunmuştu ve bu durum, 1754'te kurulacak olan Viyana Şark Dilleri Akademisi'nde de sürdü. ${ }^{72}$ Henüz XVII. yüzyılın başından itibaren tercümanlarla saray tercümanları arasında imparatorluk yapısı içerisinde bir ayırım mevcuttu. Bu ayırım maaşlara da yansıyordu. Saray tercümanlarıyla diğer tercümanlar arasındaki en büyük ayırım görev ve sorumluluk açısındandı. Saray tercümanları, "güvenilir" kişiler olarak görülüp önemi yüksek diplomatik misyonlar üstlenirdi. Örneğin Michel d'Asquier, saray tercümanlığına getirildiği yıl olan 1625'te önce Gyarmat, iki yıl sonra da Szöny barış müzakerelerinde görev ald. ${ }^{73}$ Fakat denilebilir ki saray tercümanlarının asıl görevi, Viyana’ya gelen Osmanlı elçilik heyetleri ile kayzerî makamların temsilcileri arasında iletişimi sağlamak, elçilikleri karşılamak, ${ }^{74}$ elçiliklere ağırlandıkları süre zarfında yardımcı olmak ve rehberlik hizmeti sunmaktı. Önemli bir diğer fonksiyonları, Osmanlı elçilerinin resmî ziyaretlerinde ve huzura kabul merasimlerinde bulunuyor olmalarıydı. Teşrifata göre kimin kime ne kadar yaklaşması gerektiği gibi hassas konularda elçiyi bilgilendiriyorlardı. O sırada Habsburg ricâli ile elçi arasındaki iletişimi genellikle elçilerin yanlarında bulunan tercümanlar sağlasa da, saray tercümanlarına başvurulduğu da oluyordu. ${ }^{75}$

Sefaretlerin Viyanàya yaklaşan yolculuk bahsine dönecek olursak, şehre törensel girişi gerçekleştirmeden evvelki son durak olan Schwechat' ${ }^{76}$ varıldığında, tercümanlar vasıtasıyla Saray Harp Şûrası ile şehre giriş günü ve saati hakkında görüşülürdü. Şûra, gerekli hazırlıkların tamamlanması için genellikle 2-3 gün sonrası için tarih verirdi. Osmanlı büyükelçilik heyetlerinin Viyana'ya girişleri esnasında onları şehir hududunda karşılamak ve kalacakları yere kadar götürmek

Südost- und Osteuropa, hg. von Gunda Barth-Scalmani, Harriet Rudolph, Christian Steppan, (Innsbruck [u.a.]: StudienVerlag, 2013), s. 270-271.

72 Detaylı bir çalışma için bkz. Ernst Dieter Petritsch, "Die Anfänge der Orientalischen Akademie", 250 Jahre: Von der Orientalischen zur Diplomatischen Akademie, hg. von Oliver Rathkolb, (Innsbruck [u.a.]: StudienVerlag, 2004), s. 47-64.

73 Balbous, Das Sprachknaben-Institut, s. 75.

74 Örneğin I. Mahmud'un cülusunu bildirmek üzere Viyana’ya gönderilen Mustafa Efendi'yi saray tercümanı Heinrich Penkler karşıladı. Penkler’e görevlendirilmesinden önce kayzerî komiser vasfı verilmişti (Wienerisches Diarium Num. 43, 30.05.1731).

75 Reiter, “... wo der Dollmetsch allzeit”, s. 205-209.

76 Günümüzde bu bölgede Viyana havalimanı yerleşkesi bulunur. 
işi (Einholung) şehrin ileri gelenlerine yaptırılırdı. XVII. yüzyılda çoğunlukla bu kişi, şehrin en yüksek temsilcisi ve şehir kapılarının anahtarlarını muhafaza eden belediye başkanı olurdu. ${ }^{77}$ 1627'deki barışın (Szöny) tecdidi için IV. Murad'ın 1634 'te III. Ferdinand'a gönderdiği maktul sadrazam Topal Recep Paşa’nın sâbık kâhyası Rıdvan Ağa, ${ }^{78}$ yaklaşı 100 kişilik maiyetiyle önce 19 Ocak’ta, aynı görevle İstanbul'a gitmek üzere olan Habsburg büyükelçisi Johann Rudolf von Puchheim ile Szöny köyü yakınlarında elçi mübadelesini gerçekleştirmiş ${ }^{79}$ ve merasimle şehre girmek için 6 Mart'ta Viyana Belediye Başkanı Daniel Ritter von Moser tarafından karşılanıp kalacağı ikametgâha (Losament) kadar götürülmüştü. ${ }^{80}$ Daha sonra karşılama görevini aynı şekilde bir diğer Belediye Başkanı Johann Georg Dietmayr 1650'de büyükelçi Hasan Paşa ve 1665'te Kara Mehmed Paşa'nın sefaretlerinde yerine getirdi. ${ }^{81}$ Karşılama görevi sırasında belediye başkanının yanında bulunan şehir muhafızları, Osmanlı elçilik heyetlerini koruyan eskort vazifesi görürdü. XVIII. yüzyıla gelindiğinde sefaretler belediye başkanlı yerine, yine şehrin dışında daha önce konuşulmuş bir noktada bu defa saray arabasıla (Hofwagen) gelen Obersthofmarschall tarafından karşılanır ve onun önderliğinde yerleştirilecekleri ikametgâha kadar götürülürdü. Eskortta yine şehir muhafızları bulunurdu. ${ }^{82}$

Şehir muhafızları (Stadtguardia), bir kale şehir olan Viyana’nın 1531 yılında kurulmuş kale muhafızları birimiydi. Muhafızlar şehrin kapılarını tutup surlarında vardiya usulüyle nöbet tutardı. 1221 yılından beri Viyanalı zanaatkârlarca sürdürülmüş olan kolluk kuvveti görevi de şehir muhafızları bünyesinde toplandı. 1556'da Saray Harp Şûrası'nın ihdasıyla birlikte şehir muhafızları Şûra’ya bağlanmış ve muhafız komutanı (Obrist) Şûra’ya asayişle ilgili düzenli bilgi aktarmaya başlamıştı. XVII. yüzyılda çoğunlukla Saray Harp Şûrası başkanlarının

77 Peter Csendes ve Ferdinand Opll (Hg.), Wien: Geschichte einer Stadt. Die frühneuzeitliche Residenz (16. bis 18. Jahrhundert), c. II, hg. von Karl Vocelka, Anita Traninger, (Wien [u.a.]: Böhlau, 2003), s. 58.

78 Hammer, GOR, V, s. 181.

79 OeStA, HHStA, Staatenabteilung (StAbt), Türkei I 113, vr. 70.

80 Gustav Freiherr von Suttner, Daniel Ritter von Moser. Georg von Gurtner. Beitrag zur Geschichte Wiens im XVII. Jh., (Wien: Gerold, 1894), s. 19. Moser, 23 yll boyunca Viyana Belediye Başkanlık görevini üstlenmiştir (1610-1614, 1616-1623, 1626-1638), aynı eser s. 1.

81 Alois Groppenberger von Bergenstamm, Geschichte des unteren Werds, oder der heutigen Leopoldstadt (Wien: Kaiserl. königl. Hof- und Staatsdruckerey, 1812), s. 139-140.

82 Johann Baptist Schönwetter, Gründ- und umständlicher Bericht von denen römisch-kayserlichen wie auch ottomannischen Groß-Bothschafften [...], (Wien: Schönwetter, 1702), s. 51. 
veya başkan yardımcılarının aynı zamanda şehir muhafızları komutanlık görevini de üstlendikleri görülür. Sayıları savaş zamanlarında kayzerî ordudaki neferlerin takviyesiyle birkaç bini bulmakla birlikte olağanüstü hâller dışında 1586'da 270 iken büyüyen şehir ve kalabalıklaşan nüfusla birlikte sayılar da arttı; 1596'da 500, 1679'da 1.202 'ye ulaştı. ${ }^{83}$ Osmanlı elçilik heyetleri bağlamında önemleri, Viyana'ya girişleri esnasında heyetlere koruma sağlamaları dışında heyetlerin Viyana'daki ikametleri boyunca ikametgâhlarındaki nöbetçilerin bu kolluk kuvvetinden oluşmasıdıd.

Osmanl1-Habsburg elçilik heyetlerinin başkente girişlerindeki mutantan merasim yürüyüşleri, gerek Viyana'da gerek İstanbul'da büyük kalabalıklarca izlendi. Sarayların temsil gücü en üst seviyede ihtişamla sahnelenmeye çalışıldı. 1634 gibi erken tarihlerde dahi, Osmanlı elçilik heyetinin büyük ilgi uyandıran şehre girişinin, çağdaş Alman neşriyatına yansıması söz konusudur. 1645'te İstanbul'dan birlikte yola çıkmış olan Kont Hermann Czernin ile Kapıcıbaşı Yusuf Ağa Viyana’ya vardığında, iki elçinin aynı anda gerçekleşen merasim yürüyüşünün görgü şahitleri arasında ünlü Harrach ailesinden kardinal ve Prag başpiskoposu Ernst Adalbert von Harrach bulunuyordu. Kardinalin günlügünde, sırf elçilik heyetlerinin yürüyüşünü görebilmek için Viyana piskoposunun evinde yemeğe kalındığı, Yusuf Ağa’nın kontun yanında iyi bir izlenim bıraktığı yazar. ${ }^{84}$ Ömründe İslâm ülkelerinden gelen birini nadiren görebilen Viyanalılar için Osmanlı sefaretlerinin şehre gelişi, başka yabancı elçilerinkinden her zaman daha büyük bir ilgiye mazhar olup kadınlı erkekli yüzlercesini bir araya topluyordu. Zira yeniçeri müziğini dinlemek, elçiyi taşıyan süslü atlı arabayı, bellerinde eğri kılıç taşıyan Osmanlı neferlerini ve sallanarak ilerleyen develeri görmek, ancak bu heyetlerde mümkündü. ${ }^{85} \mathrm{Za}$ ten Evliya Çelebi'ye bakılırsa, 1665'in Haziran ayında şehirden “[...] bir sâ'atde kâh şimâle ve kâh cenûba bizi sokak sokak gezdirüp ba'dehu Beç kal'asının cânib-i şimâlinde üç kat demir kapulardan taşra yine kütür kütür mehterhânemiz çalarak şehir içi güm güm öterek mezkûr kapudan taşra [... ." ${ }^{\prime 86}$ çıkılarak ilgi uyandırmak-

83 Alois Veltzé, “Die Wiener Stadtguardia (1531-1741)”, Berichte und Mitteilungen des Altertums-Vereines zu Wien, 36/37 (1902), s. 1-46.

84 Ernst Albrecht von Harrach, Die Diarien und Tagzettel des Kardinals Ernst Adalbert von Harrach (1598 - 1667). Band 5: Tagzettel 1644-1654, hg. von Katrin Keller, Alessandro Catalano, (Wien [u.a.]: Böhlau, 2010), s. 131.

85 Gibs, Leopoldstadt, s. 23 vd..

86 Evliya Çelebi b. Derviş Mehemmed Zıllî, Evliyâ Çelebi Seyahatnâmesi, 7. Kitap: Topkapı Sarayı Kütüphanesi Bağdat 308 Numaralı Yazmanın Transkripsiyonu-Dizini, haz. Yücel Dağlı vd. (İstanbul: Yapı Kredi Yayınları), 2003, s. 93. 
tan hiç çekinilmemiştir. Osmanlıların bu "sesli" yürüyüşlerine zamanla aşina olan Viyanalılar, 1719'da Silâhdar İbrahim Paşa ve kalabalık heyetinin gelişi sırasında bu defa hazırlıklı olarak şehrin farklı yerlerinde bekleyen müzisyenlerin davul ve trompetleriyle müzikal bir karşılama yapacak, Osmanlı mehterânı selâma sessiz kalmayarak mukabelede bulunacaktı. ${ }^{87}$ İkametgâhlarına yerleştirilen elçilik heyetleri en az bir hafta istirahat süresi geçirirdi. Bundan sonraki program, diplomatik misyonun en önemli kısmı olan, nâme-i hümayunun Kutsal Roma Alman imparatoruna teslimiydi. Huzura kabul tarihi Oberstkämmerer ${ }^{88}$ ile istişare edilirdi. Belirlenen günde elçi ve beraberindeki birkaç kişi, bu iş için görevlendirilen bir teşrifatçı (Audienzkommissar) tarafından resmikabul arabasıyla (Audienzwagen) alınıp saraya götürülürdü. ${ }^{89}$

Osmanlı elçilerinin Habsburg saraylarında resmikabulleri ve bu esnada uygulanan teşrifat birkaç istisna dışında Avrupalı meslektaşlarına eşit bir prosedüre ve niteliğe sahipti. Bunun neticesi olarak kayzerin huzuruna kabul edildikleri gibi saraylarda tertiplenen kayzerî merasimlere de iştirak edebiliyorlardı. Eğer gelen elçiler büyükelçi vasfında değilse, arza girmeleri gerçekleşmekle birlikte uygulanan teşrifat çok daha sadeydi. Bununla birlikte, Osmanlı elçilerine has bazı uygulamalar da söz konusuydu. Evvela, sefaretler Viyana’ya vardığında ve Viyana'dan ayrilmadan, elçi ve beraberindeki -çoğu kez 15 kişiyi geçmeyenseçkin maiyeti kayzerin yanı sıra dönemin Saray Harp Şûrası başkanının da huzuruna kabul edilirdi. Her iki ziyarette de elçiliğin yanında getirdiği "ağır" hediyeler takdim edilirdi. ${ }^{90}$ Saray Harp Şûrası başkanına yapılan resmî ziyaretin öne çıkan iki sebebinden ilki, Osmanlılarla askerî ve diplomatik ilişkilerden baş sorumlu kişi olmasıdır. İkincisiyse mütekabiliyettir. Bilindiği üzere Habsburg

87 Wilhelm Kisch, Die alten Strassen und Plätze von Wien's Vorstädten und ihre historisch interessanten Häuser [... J, c. I, (Wien: Verlag von Oskar Frank’s Nachfolger, 1888), s. 65 dipnot 2.

88 Hammer'e göre Osmanlı sarayındaki kapıcılar kâhyasına karşılık gelir, bkz. Hammer, Des osmanischen Reichs Staatsverfassung, s. 94.

89 Seitschek, "Einige caeremonialpuncten bet(reffend)", s. 175. Tarihî sürecinde huzura kabul konusu bu makalenin amacına hizmet etmediğinden ve konunun muhtevası müstakil bir makalede ele alınmasını gerektirecek kadar hacimli olduğundan burada bu konu üzerinde etraflıca durulmamıştır.

90 Bu konuda yapılmış bir çalışma için bkz. Hedda Reindl-Kiel, "Symbolik, Selbstbild und Beschwichtigungsstrategien: Diplomatische Geschenke der Osmanen für den Wiener Hof (17.-18. Jahrhundert)", Frieden und Konfliktmanagement in interkulturellen Räumen. Das Osmanische Reich und die Habsburgermonarchie in der Frühen Neuzeit, hg. von Arno Strohmeyer, Norbert Spannenberger, (Stuttgart: Franz Steiner Verlag, 2013), s. 265-282. 
elçileri İstanbul'da sultanın yanı sıra Paşakapısı'nda sadrazamın da huzuruna çıardı.

Osmanlılarla uzun süredir yaşanan siyasal rekabetin yarattığı psikolojinin ve en azından II. Viyana kuşatmasına kadar devam eden -Kanuni Sultan Süleyman'dan beri zihin dünyalarının ayrılmaz bir parçası olan- korkulu Türk algısının dışavurumu olarak yorumlanabilecek şekilde, Osmanlılara resmikabul gününde ikametgâhlarından saraya kadar diğer yabancı elçiler için yaygın olduğu şekliyle kayzerin saray hizmetkârları ve Müşavir-i Has üyeleri değil, ağırlıklı olarak şehir muhafızları, kayzerî ordunun subayları ve Türk kıyafetleri giydirilmiş memurlar eşlik ederdi. ${ }^{91}$ Diğer yandan erken modern Avrupa tarihinin en önemli gelişmelerinden sayılan Martin Luther hareketine bağlı olarak cereyan eden Protestan-Katolik mücadelesinin bir ayağı diplomasi ve imparatorluk saraylarındaki hiyerarşideki öncelik olurken, ${ }^{92}$ Osmanlılar bu çetin sürtüşmenin uzağında olmanın avantajlarını yaşadı. 20 Ağustos 1719'da Avusturya Arşidüşesi Maria Josepha ile Saksonya Elektör Prensi Güçlü August'un (August der Starke) oğlu II. Friedrich August'un geniş yankı uyandıran dügünleri vesilesiyle kayzerî yazlık sarayın (Favorita) opera salonunda gerçekleştirilen Katolik törende, dinî sebeplerden ötürü yaşanabilecek bir tatsızlığın gölgesi düşmesin diye Avrupa'nın Protestan devletlerinin temsilcileri davet edilmezken, merasimi Silâhdar İbrahim Paşa kimliği gizlenmiş olarak locadan takip etmişti. ${ }^{93}$

Saray Harp Şûrası başkanına yapılan resmî ziyaret sırasındaki parlak karşılama törenleri kayzer huzurundakileri aratmayacak ölçüdeydi. 1703’te I. Leopold tarafından Şûra'nın başkanlığına getirildikten itibaren bu görevi 33 yıl boyunca ölümüne kadar sürdüren Prens Eugen zamanındaki huzura kabullere dair çağdaş kaynaklarda çok sayıda yazılı ve görsel malzeme bulmak mümkündür. Bunun nedeninin, prensin imparatorluktaki siyasî konum ve henüz hayattayken sahip olduğu yüksek tanınmışlıkla ilgili olduğu söylenebilir. Seyfullah Ağa (1711), Müteferrika İbrahim Ağa (1715) ve Silâhdar İbrahim Paşa (1719) prensin Habsburglar

91 Andreas Pečar, Die Ökonomie der Ehre: der höfische Adel am Kaiserhof Karls VI. (1711 1740), (Darmstadt: Wissenschaftliche Buchgesellschaft, 2003), s. 215-216.

92 Bu mücadele Hıristiyan dünyanın dışında, İstanbul'da da yaşandı. Habsburg mukim elçisi Rudolf Schmid Pera'daki kilisede yapılan Kuddas ayini sırasında Katolikliğin üstünlüğünü sağladığını gururla anlatır, bkz. Ercan, "Osmanlı-Habsburg Diplomasisi", s. 143.

93 OeStA, HHStA, Zeremonialprotokolle 10 (1717-1719), vr. 367; İbrahim Paşa’nın bu "gizli” şahitliği Viyana gazetesinde haber olmuştu, bkz. Wienerisches Diarium, Num. 1675, 19.08.1719. 
nezdindeki itibarının yansıması olarak kendisine tahsis edilmiş Avusturya barok mimarisinin en görkemli yapılarından biri sayılan Viyana’nın merkezindeki kışlık sarayında (Winterpalais) kabul edilmişti. Seyfullah Ağa'nın ve maiyetinin burada gerçekleştirdiği resmî ziyareti esnasında sarayın önünde karşılanışı, dönemin en ünlü barok mimarlarından ve imparatorluk adına -kışlık sarayı gibi- abidevî eserlere imza atmış Johann Bernhard Fischer von Erlach'ın ${ }^{94}$ bir bakır hakkâk resmine konu olmuştu (Ek III). Yine Prens Eugen tarafından kabul edilen ilk Müslüman şehbender Kazgancızâde Ömer Ağa (1726) ve Tavukçubaşı Damadı Mustafa Efendi (1731) ise bu defa prensin kendi siparişiyle inşa ettirdiği meşhur sarayının (Schloss Belvedere) resmikabul ve merasim sarayına (Oberes Belvedere) davet edildiler. Daha sonraları Cânibî Ali Paşa (1740) prensin halefi Johann Philipp Harrach tarafindan kabul edilmişti. Tüm bu resmikabullerin ortak yönü, törenlerin Osmanlılarda olduğu gibi ciddiyet içeren bir havada, oldukça sessiz ve az sayıdaki devlet görevlilerin nezdinde gerçekleşmesi yerine kalabalık bir topluluğun meraklı bakışları altında canlı ve şenlikli oluşuydu.

\section{Osmanlı Elçilik Heyetlerinin Viyana'daki İkametgâhları ${ }^{95}$}

Kutsal Roma Alman İmparatorluğu’nun Prag'dan sonra I. Ferdinand döneminde rezidansı konumuna yükseltilen ${ }^{96}$ surlarla çevrili Viyana'da (Ek I), Osmanlı payitahtına XVI. yüzyılın ilk çeyreğiyle XVII. yüzyılın ortaları arasında gelen Habsburg elçilerinin oturmak zorunda olduklarr, ${ }^{97}$ gece gündüz başında yeniçeriler bekleyen tek kapısıyla ünlü ${ }^{98}$ Nemçe Hanı'nın ${ }^{99}$ muadili bir yapı bulunma-

94 (Çevrimiçi) https://www.deutsche-biographie.de/sfz16314.html\#ndbcontent, 11.02.2019.

95 Habsburglara gönderilmiş ve Viyana dışında Prag ve Linz şehirlerinde de bulunmuş Osmanlı elçilik heyetleri vardır.

96 Harriet Rudolph, "Yeniçağ’n Başlangıcında İmparatorlukta Türk Elçileri-1562'de İbrahim Bey’in Elçiliği Örneğinde İktidarın Sergilenmesi, Yabancıyla Karşılaşma Tecrübesi ve Hatırlama Kültürü”, çev. Ayșe Killç, İstanbul Üniversitesi Edebiyat Fakültesi Tarih Dergisi, 63 (2016), s. 134. 97 Karl Teply, "Nemçe İmparatorlarının İstanbul'a Yolladığı Elçi Heyetleri ve Bunların Kültür Tarihi Bakımından Önemli Tarafları”, çev. Bekir Sıtkı Baykal, Ankara Üniversitesi Tarih Araştırmaları, XII (1969), s. 257.

98 Ernst D. Petritsch, "Zeremoniell bei Empfängen habsburgischer Gesandtschaften in Konstantinopel", Diplomatisches Zeremoniell in Europa und im Mittleren Osten in der frühen Neuzeit, hg. von Ralph Kauz, Giorgio Rota, Jan Paul Niederkorn, (Wien: Verl. der Österr. Akad. der Wiss., 2009), s. 310.

99 Elçi/Nemçe Hanı, 1509-1512 yılları arasında İstanbul Çemberlitaş่ta Atik Ali Paşa Camii ve Külliyesi'nin parçası olarak yapılmıştır. İstanbul'a gelen birçok yabancı elçi bu hanı 
maktadır. Osmanlı elçilerini 1634’te gelen Rıdvan Ağa’ya kadar suriçi Viyana’nın muhtelif pansiyonları/misafirhaneleri ağırlamıştı. Örneğin 1562 Ekim’inde $^{100}$ Beç Kalesi'nde birkaç gün ikamet eden İbrahim Bey ve maiyeti, imparatorluk sarayına (Hofburg) neredeyse bitişik konumdaki saray hastanesinin (Hofspital) ${ }^{101}$ misafirhanesine yerleştirilmişti ve 1620'de Budin'den yollanan bir çavuş, aynı yıl iki defa olmak üzere yine sarayın çok yakındaki Zum Weissen Schwan ${ }^{102}$ isimli misafirhanede ağırlanmıştı. ${ }^{103}$

Habsburg yönetimi, 1609'a kadar mevcudu nadiren 20 ilâ 30 kişiyi geçen Osmanlı elçilik heyetlerinin hem sayıca artması hem ikamet sürelerinin uzamas1 üzerine bu kalabalık zümrenin ağırlanma işinin, Orta Çağ’da Unterer Werd, 1670'lerden itibaren Leopoldstadt ${ }^{104}$ (Ek II) ismini alan ve Tuna nehriyle nehrin bir kolu arasında bulunan varoştaki muhtelif misafirhaneler (Gasthäuser) tarafından üstlenilmesi gerektiğini uygun görmüştü. ${ }^{105}$ Zaten burası, Avusturya Dükü V. Albrecht'in ${ }^{106}$ transit yolcuların (Durchreisende), suriçine nazaran daha fazla mes-

gördüğü gibi bir kısmı da burada ikamet etmiştir, Semavi Eyice, "Elçi Hanı”, İstanbul Üniversitesi Edebiyat Fakültesi Tarih Dergisi, 24 (1970), s. 93-130. Bu handa ayrıca çok sayıda Orta Avrupa elçisinin yanında haraçgüzâr devletler olan Erdel, Eflâk ve Boğdan elçilerinin kalması, Habsburg kapı kethüdalarının merkeze yolladıkları raporlarda birçok kez şikâyet konusu olmuştur.

100 Rudolph, "Yeniçă̆’ 1 Başlangıcında", s. 20.

101 Teply, "Türkische Gesandtschaften", s. 18. Bu bina daha sonra büyütülerek Kaiserspital ismini alır, bkz. (Çevrimiçi) https://www.geschichtewiki.wien.gv.at/Kaiserspital, 26.01.2019.

102 (Çevrimiçi) https://www.geschichtewiki.wien.gv.at/Zum weißen Schwan, 26.01.2019.

103 OeStA, FHKA, Reichsakten, Fz. 278, vr. 32.

104 Günümüzde II. Viyana İlçesi. Bu bölgede eskiden bir Yahudi Mahallesi bulunup 1669'da Kutsal Roma Alman İmparatoru I. Leopold'un (ö. 1705) talimatıyla ortadan kaldırıldı; Yahudiler tehcir edildi. Aynı yerde bulunan bir sinagogu yıktırıp yaptırdığı, kendi ismini taşıyan ve 6 Eylül 1671'de açılan kilise ile ilçe yeni ismini aldı, bkz. Helga Gibs, Leopoldstadt: kleine Welt am großen Strom, (Wien: Mohl, 1997), s. 11, 13.

105 Bu tarihten sonrası için istisnaî bir örnek, 1689'da Zülfikâr Efendi ve yaklaşık 100 kişilik maiyetinin kalmış olduğu, Viyana surlarının Güney-Doğusunda bulunan Stubentor kapısından şehirden çıkınca başlayan Landstrasse üzerindeki Zum Goldenen Engel veya Vollandisches Haus misafirhanesidir. Bkz. Wolfgang Jobst, "Der Gesandtschaftsbericht des Zülfikâr Efendi über die Friedensverhandlungen in Wien 1689” (doktora tezi), Universität Wien, 1980, s. 237 dipnot 169.

106 1438-1439 arasında II. Albrecht ismiyle Roma Alman Kralı. 
ken barındıran bu bölgedeki misafirhanelerde konaklaması gerektiğine dair 1433 yılında verdiği hükümden beri gerek ticaret ve ziyaret için gelen zümrenin, gerek seyyahların, gerekse sarayda bir görüşme gerçekleştirmek niyetine sahip asillerin ve rütbelilerin konaklama mevkii olmuştu.

1669 yılında 136 binası varken ${ }^{107}$ Kayzer I. Leopold ile birlikte yapılaşması ve nüfusu daha da artan varoşu şehrin müstahkem surlarından ayıran Tuna kolundan geçmenin 1782'ye kadarki tek yolu 1361'de yapılan tarihî Schlagbrücke $e^{108}$ üzerinden geçmekti. Bu mevki şehir tarihi açısından aynı zamanda bir başka önemi haizdi: Köprü ayaklarının bulunduğu sahil kısmı, Habsburgların Tuna nehri üzerinden elçilerini gemilerle uğurladıkları yer olma özelliğini taşırdı. 1628'de Hans Ludwig von Kuefstein'in Dersaâdet'e yolculuğu 20 Temmuz'da 11 gemiyle buradan başlamış ve Kuefstein, maiyetinde bulunan Franz Hörmann’a elçiliğinden kesitler sunan bir dizi guaj boya resmi sipariş etmişti. Bu koleksiyonda şehirden ayrılış sahnesi de yer alır. ${ }^{109}$

Nehir kolunun karşı tarafında bulunan ve XVI. yüzyılın ortalarından itibaren gece-gündüz nöbeti tutulmaya başlanan kale şehrin kapıları hava karardıktan sonra kapalı tutulurdu. ${ }^{110}$ Giriş ve çıkışlar yazılı özel izni bulunanlar dışında herkese yasaktı. 1626 yılına kadar katı bir biçimde uygulanan bu geçiş yasağı, gümrük vergisi getirilmek suretiyle yumuşatıldı. ${ }^{111}$

Osmanlı elçilik heyetlerinin Habsburg topraklarına varmasıyla birlikte haberdar edilen Saray Harp Şûrası, elçiliğin gelişini ve heyetin mevcudunu -çoğu zaman yaklaşık olarak- Maliye Dairesi'ne bildirirdi. Bunun üzerine sefaretlerin nereye yerleştirilecekleri konusu gündeme gelirdi. Maliyeden görevlendirilen bir

107 Gibs, "Leopoldstadt", s. 12.

108 Önce yerine 1819 'da Ferdinandsbrücke, sonra 1909'da çelik malzemeyle bir kemerli köprü yapıldı. II. Dünya Savaşı'nın son safhasında Nisan 1945'te Viyana Savaşı esnasında büyük hasar görüp tadilattan sonra 1946'da tekrar kullanıma açıldı. 1957'de yıkılarak Viyana'nın ilk öngerilmeli beton köprüsü olan günümüzdeki Schwedenbrücke inşa edildi, bkz. (Çevrimiçi) https://www.geschichtewiki.wien.gv.at/Schwedenbr\%C3\%BCcke, 26.01.2019.

109 Karl Teply, Die kaiserliche Großbotschaft an Sultan Murad IV. im Jahre 1628, (Wien: A. Schendl, 1976), s. 37, 60, 113.

110 Şehir kapılarının kapanış saatleri zaman içerisinde birden çok değişikliğe uğramıştı. Fikir vermesi için 1703 yılına ait uygulamaya bakıldığında, kapıların kışın ortalama saat 17:00'de, yazın ise ortalama olarak saat 19:00'da kapatıldığı görülür (Veltzé, “Die Wiener Stadtguardia”, s. 125).

111 Peter Csendes ve Ferdinand Opll (Hg.), Wien, s. 76-77. 
memur Leopoldstadt'taki misafirhanelerle temasa geçerdi. Birden çok misafirhaneyle görüşülmesinin sebepleri, yer durumuna göre müsait ve hazineye en az külfet getirecek olanı bulabilmekti. XVII. yüzyılın ikinci yarısında heyet mevcudunun artmasıyla birlikte en uygun fiyatı veren işletme sahibiyle, maliyeti daha da azaltmak için pazarlık da yapılırdı. ${ }^{112}$ Nihâ̂ kararı verenin Saray Harp Şûrası olduğu, 1662'de Temeşvar Valisi Ali Paşa tarafından gönderilen Kapıcıbaşı Abdurrahman Ağa’nın Viyana'ya, o sırada Saray Harp Şûrası başkan yardımcısı ve şehir muhafız komutanı olan Annibale Gonzaga'ya ${ }^{113}$ danışılarak yerleştirilmiş olması gibi örneklerden anlaşılmaktadır. ${ }^{114}$ Son kertede ihtiyaca göre bir veya birden fazla misafirhaneyle anlaşılıp bir sözleşme (Contract) düzenlenirdi. ${ }^{115}$

Leopoldstadt'in Osmanlı kaynaklarındaki bilinen ilk tasviri, Vasvár barışı çerçevesinde iki devlet arasındaki dostluğun takviyesi ve hediye takdimi amacıyla 1665 yllında Viyana'ya gönderilen Kara Mehmed Paşa'nın heyetinde yer alan ve protokolde bulunan Evliya Çelebi tarafından yapıldı:

"[...] İki Tuna mâbeyninde bir cezîre-i tavîlde üç bin aded bağ u bağçeli serâpâ kârgîr âlî ve tahta ve kiremit örtülü ikişer ve üçer kat vâsi' sarây-1 azîmler cümle elçi paşaları ve Budin tarafından gelen elçileri bunda kondururlar, Tuna kenârında karşu Beç'e nâzır ma'mûr hânelerdir ve altları cümle anbâr ve mahzenlerdir. Ve tersâhâne iskelesi ve gemiler yapılacak yerler cümle bu varoşdadır ... cümle varoşdan mu'azzam mezkûr şehr-i Peşpehil'dir. Andan sonra bizim oturduğumuz Elçi Paşa varoşu ma'mûr ve müzeyyendir $[\ldots] .{ }^{116}$

Yabancı isimlerin Osmanlı belgelerinde birden fazla varyasyonla yer bulmasına dair sayısız örnekten biri Leopoldstadt kelimesidir. İbrahim Paşa Sefaretnâmesi'nde "Lebolştok"117 ve Ahmed Resmî Efendi Sefaretnâmesi'nde "Lobdoş"118 şeklinde yazılıyken Evliya Çelebi Seyahatnâmesi'nde "Süveyde"119 diye tabir olunur.

112 Perger ve Petritsch, "Der Gasthof”, s. 161.

113 (Çevrimiçi) https://www.geschichtewiki.wien.gv.at/Annibale Franz Maria Gonzaga,

31.01.2019.

114 OeStA, FHKA, Reichsakten, Fz. 306.14, vr. 336.

115 1740'da Cânibî Ali Paşa'nın ağırlanmasına dair sözleşme için bkz, OeStA, FHKA,

Kontrakte und Reverse, C-1373.

116 Evliyâ Çelebi Seyahatnâmesi, s. 99.

117 Kraelitz-Greifenhorst, "Bericht über den Zug", s. 45.

118 Ahmed Resmi Efendinin Viyana ve Berlin Sefaretnameleri, haz. Bedriye Atsız, (İstanbul:

Tercüman, 1980), s. 20.

119 Evliyâ Çelebi Seyahatnâmesi, s. 99. 
Bâbıâlî tarafından Viyana’ya gönderilen ve maiyetleri sayıca az olan elçilikler Leopoldstadt'ın sayısı on ikiyi bulan çeşitli meskenlerinde konaklamıştı. Bu cümleden, Nisan 1711'de Seyfullah Ağa, Mayıs 1715'te Müteferrika İbrahim Ağa "Leixingerisches Haus", ${ }^{120}$ Mayı 1748'de Mustafa Hattî Efendi ve Nisan 1755'te Hacı Halil Efendi "Graf Oettingisches Haus"121 örnekleri verilebilir. Bununla birlikte 1634 ilâ 1774 yılları arasında muvakkat ikametlerini gerçekleştirmiş olan elçilik heyetlerini ${ }^{122}$ en sık ağırlayan yer "Zum Goldenen Lamm"123 olmuştu.

Burası Tabor ve Prater caddelerinin başında yer alan ve geçmişi 1430'a kadar takip edilebilen, ortasında geniş avlusu bulunan iki katlı büyük bir binaydı. ${ }^{124}$

120 Obere Donaustraße 87 'de bulunan, bir ambara ve büyük bir mutfağa sahip 11 odalı bu bina, 22 kişiden oluşan 1715 'teki heyet için yeterli ölçüde geniş bulunmuş ve haftalık 80 Guldenlik bir bedelle kiralanmıştır, bkz. Karl Teply, "Karl Eugen Leopoldstätter alias Mehmed Effendi - ein hofbefreiter Kaffeesieder im Wien Kaiser Karls VI.", Wiener Geschichtsblätter, 27 (1972), s. 377 dipnot 13. Seyfullah Ağa Sefaretnâmesi'nde bu yap1 için "[...] bir âlî saray konak tảyin olunmuş [...]" ifadesi kullanılır (Kemal Beydilli ve İsmail E. Erünsal, "Prut Savaşı Öncesi Diplomatik Bir Teşebbüs: Seyfullah Ağa’nın Viyana Elçiliği (1711)”, TTK Belgeler, XXII/26 (2002), s. 7, 21 dipnot 110).

121 Wienerisches Diarium, Extra-Blatt zu Num. 41, 22.05.1748. "Eggerischer Garten” ve "Haus Öttingen und Garten" olarak da anılan büyük bir bahçe içerisinde yer alan bu bina 1789 'da "Grassalkovicspalais” adını alacak bir saraya dönüştürülmüştür, bkz. (Çevrimiçi) https://www.geschichtewiki.wien.gv.at/Grassalkovicspalais, 26.01.2019. Mustafa Hattî Efendi Sefaretnâmesi'nin neşrinde, bu binanın "Graf Detting Sarayz" olduğu bilgisi verilmiştir (Mustafa Hattî Efendi, Viyana Sefâretnâmesi, s. 29 dipnot 149). Hâlbuki bu isimde bir yapı bulunmamaktadır. Bu durumun, Wienerisches Diarium’da yer alan bilginin yanlış okunmasından kaynaklandığı düşünülebilir.

122 Tarih aralığı 1635-1774 olarak da verilmektedir, bkz. Perger ve Petritsch, "Der Gasthof”, s. 164. Bu elçilerin tamamı büyükelçi değildir. Sözgelimi Ahmed Resmî Efendi (şıkk-1 sânî defterdarlığı pâyesiyle) ve Süleyman Bey (başmuhasebe pâyesiyle) "fevkâlade" elçiler olup (Bekir Kütükoğlu, "Ahmed Resmî”, TDV İlâm Ansiklopedisi, 1989, II, 121; Mehmed Süreyya, "Sicill-i Osmanî", c. 5, s. 1531-1532; Wienerisches Diarium, Supplement zu Num. 30, 15.04.1758) Mustafa Efendi ise defterdâr-1 şıkk-1 sânî pâyesiyle özel elçidir (Mesut Aydıner, "Mustafa Efendi, Tavukçubaşı Damadı", TDV İlâm Ansiklopedisi,, 2016, EK-II, 326-328). Süleyman Bey Avusturya arşivindeki Saray Harp Şûrası protokolünde de "ausserordentlich" (fevkalâde) ve "in eigenschaft eines zweiten Defterdars" (şıkk-1 sânî defterdarı vasfinda) diye geçer (OeStA, Kriegsarchiv, Hofkriegsrat Protokollen 1028, 58/5).

123 "Altın Kuzuya” şeklinde tercüme edilebilen bu yapı XVI. yüzyıl belgelerinde Zum gulden Lämpl ismiyle anılır.

124 Yapı, günümüze ulaşamamıştır. 1770'te büyük bir yangın atlatmış, 1872'de büyütülerek otel vasfinı sürdürmüş ve 1888 'de Hotel Continental ismini almıştır. II. Dünya Savaşı 
(Ek VI). Osmanlı kaynaklarında bu yapı, konak ve saray şeklinde tabir olunur. ${ }^{125}$ Zemin katında 122-145 atı barındırabilecek ahırlar, kilerler, hizmetçiler için yatakhaneler, odalar ve büyük bir nöbetçi odası mevcuttu (Ek IV). Üst katta ise büyük bir sofa ve resmikabul odası, kemerli bir salon ve hizmetliler için bölümlerle heyetin protokolünde yer alan ricâl ve elçi için yatak, oturma ve çalışma odaları bulunur, üst kata zeminde bulunan iki ayrı yerden çıkılabilirdi (Ek V).

Osmanlı sefaretlerinin Leopoldstadt'ın bu en konforlu misafirhanesinde konaklaması kesinleşip geliş tarihi belli olduktan sonra burası, dönemin işletmecisi tarafından Türk misafirlerinin beğeni ve zevklerine göre, bilhassa halı ve minderlerle döşenirdi. ${ }^{126}$ Geliş günüyse ikram edilmek üzere içme suyu ve atıştırmalıklar hazırlanırdı. İkametgâhı Zum Goldenen Lamm olan Osmanlı elçilik heyetlerini kronolojik olarak şu şekilde sıralamak mümkündür: ${ }^{127}$

\begin{tabular}{|c|c|c|}
\hline Viyana'ya Geliş Tarihi & Elçi & $\begin{array}{r}\text { Heyet } \\
\text { Mevcudu }\end{array}$ \\
\hline 1634 (6 Mart $)^{128}$ & Rıdvan Ağa & $\pm 100^{129}$ \\
\hline
\end{tabular}

sırasında ağır hasar gördüğünden restore edilememiştir. Şimdi yıkılan binanın yerinde -güneyindeki parsellerle birlikte- bir sigorta şirketinin (Uniqa Versicherung) merkez binası bulunur. Ayrıntılı ve binanın sahiplerine ilişkin bilgi için bkz. Perger ve Petritsch, "Der Gasthof", s. 153-158.

125 Evliyâ Çelebi Seyahatnâmesi, s. 93; Kraelitz-Greifenhorst, "Bericht über den Zug”, s. 40.

126 Perger ve Petritsch, "Der Gasthof”, s. 166. Buna ilişkin en erken kayı 1665 yılına ait olmakla birlikte uygulamanın 1774'de, Süleyman Bey'in elçiliği sırasında da sürdüğünü Viyana gazetesi haber verir (Wienerisches Diarium, Num. 47, 11.06.1774).

127 Hemen ifade edilmelidir ki bu liste ilk defa 1812 yılında (Bergenstamm, Geschichte des unteren Werds, s. 139-140) ve daha sonra geliştirilerek 1999'da tekrar oluşturulmuştur (Perger ve Petritsch, "Der Gasthof”, s. 164). Fakat listenin son hâlinde bulunan bazı eksik ve hatalı bilginin listeden istifade edecek yeni çalışmalara intikal etmemesi amacıyla tashihine lüzum görülmüştür.

128 OeStA, FHKA, Reichsakten, Fz. 278.38, vr. 185 ayrıca Fz. 302.63, vr.2. Sadece yıl bilgisi için bkz. Bergenstamm, Geschichte des unteren Werds, s. 139. Yil mükerreren hatalı bir şekilde 1635 olarak da verilir, bkz. Meyer, Theatrum Europaeum, III (1670), s. 165; Albin Czerny, Ein Tourist in Oesterreich während der Schwedenzeit (Linz: Ebenhöch, 1874), s. 29; Perger ve Petritsch, "Der Gasthof", s. 159, 164.

129 Geniş ölçekli bir taramaya rağmen Rıdvan Ağa'nın heyet mevcudunun tam sayısına rastlanılmamıştır. Ancak yaklaşık sayıyı vermek mümkündür, zira aynı sırada İstanbul'a gönderilen kayzerî büyükelçi Puchheim’in heyeti -kendi nihaî raporunda yer aldığı şekliyle- 100 kişiden müteşekkildir ve Osmanlı heyet mevcudu da buna yakın olmalıdır. 


\begin{tabular}{|l|l|r|}
\hline Viyana'ya Geliş Tarihi & Elçi & $\begin{array}{r}\text { Heyet } \\
\text { Mevcudu }\end{array}$ \\
\hline $1645(31 \text { Mayıs })^{130}$ & Kapıcıbaşı Yusuf Ağa $^{131}$ & $120^{132}$ \\
\hline $1650(10 \text { Kasım })^{133}$ & Hasan Paşa $^{134}$ & $144^{135}$ \\
\hline $1659(21 \text { Şubat })^{136}$ & Müteferrika Mehmed Ağa $^{137}$ & $30^{138}$ \\
\hline $1665(8 \text { Haziran })^{139}$ & Kara Mehmed Paşa & $299^{140}$ \\
\hline $1700{\text { (30 Ocak })^{141}}^{16}$ & İbrahim Paşa & $571^{142}$ \\
\hline
\end{tabular}

Raporda ilginç bir şekilde kendi heyet mevcudu için "ungefähr" (yaklaşık olarak) ifadesi kullanılırken Rıdvan Ağa’nın heyet mevcudu içinse "etliche” (çok sayıda) tanımlaması yapılır, sayı verilmez (OeStA, HHStA, StAbt, Türkei I 113, vr. 71).

130 OeStA, FHKA, Reichsakten, Fz. 280.20, vr. 9; Meyer, Theatrum Europaeum, V (1651), s. 1734. Sadece yll bilgisi için bkz. Rudolf Neck [u.a.] (Hg.), Österreich und die Osmanen. Gemeinsame Ausstellung der Österreichischen Nationalbibliothek und des Österreichischen Staatsarchivs, (Wien: Österreichische Staatsdruckerei ,1983), Kat. Nr. 134, s. 91. Katalogda dikkati çeken husus, elçilik heyetinin Zum Goldenen Lamm'da kaldıkları sonucunun, yüksek masrafları sebebiyle çıkarılabileceğinin ifade edilmesidir. Hâlbuki böylesi bir varsayıma lüzum bırakmayacak şekilde konutun ismi zikredilir, bkz. OeStA, FHKA, Reichsakten, Fz. 304.2, vr. 125.

131 Belgelerde elçinin ismi değişik şekillerde yazılmıştır: "Joseph Aga” (OeStA, FHKA, Reichsakten, Fz. 304.2, vr. 123), "Vsüff Bassa" (Fz. 304.2, vr. 112/1) ve Osmanlıca "Yûsuf Ağa" (Fz. 304.2, vr. 80).

132 OeStA, FHKA, Reichsakten, Fz. 304.2, vr. 75.

133 Bergenstamm, Geschichte des unteren Werds, s. 139.

134 Meienberger, Johann Rudolf Schmid, s. 122.

135 OeStA, FHKA, Reichsakten, Fz. 307.6, vr. 8.

136 Kisch, Die alten Strassen und Plätze, s. 64 dipnot 2.

137 OeStA, HHStA, ÄZA 6-23, vr. 2; Österreich und die Osmanen, Kat. Nr. 138, s. 93.

138 Martin Meyer, Diarium Europaeum Insertis quibusdam, maximè verò Germano-Gallo-Hispano-Anglo Polono Sueco-Dano-Belgo-Turcicis Actis Publici, II (Franckfurt am Mäyn: in Verlegung Wilhem Serins, 1659), s. 155.

139 Hammer, GOR, III , s. 578.

140 Österreich und die Osmanen, Kat. Nr. 158, s. 106. Aynı yerde, sefaretin bir kısmının 1645 ve 1650 yıllarında olduğu gibi “Zum Blauen Igel' isimli meskene yerleştirildiği bilgisi yer alır.

141 Bergenstamm, Geschichte des unteren Werds, s. 140.

142 Murat Uluskan, "Bir Osmanlı Elçisinin Yolculuk Hazırlığı: İbrahim Paşa’nın 1699 Avusturya Elçiliği”, Türklük Araştırmaları, 20 (2008), s. 255. İbrahim Paşa’nın elçilik 


\begin{tabular}{|c|c|c|}
\hline Viyana'ya Geliş Tarihi & Elçi & $\begin{array}{r}\text { Heyet } \\
\text { Mevcudu }\end{array}$ \\
\hline $1704(28 \text { Mayıs })^{143}$ & Mîr-i alem İbrahim Efendi & $30^{144}$ \\
\hline 1719 (14 Ağustos) & Silâhdar İbrahim Paşa & $763^{145}$ \\
\hline $1726(24 \text { Haziran })^{146}$ & Kazgancızâde Ömer Ağa & $+100^{147}$ \\
\hline $1731{\text { (26 Mayıs })^{148}}^{14}$ & Tavukçubaşı Damadı Mustafa Efendi & $62^{149}$ \\
\hline 1740 (4 A ğustos $)^{150}$ & Cânibî Ali Paşa & 922 \\
\hline $1755(12 \text { Nisan })^{151}$ & Hacı Halil Efendi & $53^{152}$ \\
\hline $1758{\text { (13 Mart })^{153}}^{13}$ & Ahmed Resmî Efendi & $61^{154}$ \\
\hline $1774(10 \text { Haziran })^{155}$ & Kabakulak Yeğeni Süleyman Bey & $69^{156}$ \\
\hline
\end{tabular}

heyetine dair Avusturya kaynakları 520 ve 659 gibi farklı sayılar vermektedir, krş. Perger ve Petritsch, "Der Gasthof”, s. 162; Teply “Türkische Gesandtschaften”, s. 19.

143 OeStA, HHStA, $\ddot{Z} Z A$ 50, vr. 20-38, vr. 170.

144 Meyer, Theatrum Europaeum, XVII (1718), s. 74.

145763 veya 873, bkz. Petritsch, “Türken in der Wiener”, s. 111.

146 Elçilik heyeti bu tarihte saray tercümanı Leopold von Talman tarafından Viyana’da St.

Marx’ta karşılanmış ve Zum Goldenen Lamm'a götürülmüştür, bkz. Wolfgang Klesl,

"Leopold von Talman: ein österreichischer Diplomat des Spätbarocks" (doktora tezi), Universität Wien, 1967, s. 22.

147 Heidrun Wurm, "Entstehung und Aufhebung des osmanischen Generalkonsulates in

Wien (1726-1732). Eine Relation Heinrich von Penklers aus dem Jahr 1761”, Mitteilungen des Österreichischen Staatsarchives, 42 (1992), s. 168.

148 OeStA, HHStA, $\ddot{A Z A ~ 35, ~ v r . ~} 8$.

149 Aydiner, "Mustafa Efendi", s. 326.

150 Wienerisches Diarium, Num. 63, 06.08.1740.

151 OeStA, HHStA, ̈̈ZA 50, vr. 8; Wilhelm Kisch, Die alten Strassen und Plätze von Wien's Vorstädten und ihre historisch interessanten Häuser, c. I, (Wien: Verlag v. Oskar Frank's Nachfolger, 1888), s. 64 dipnot 2.

152 Wienerisches Diarium, Num. 32, 19.04.1755.

153 OeStA, HHStA, $̈ Z A$ 51, vr. 5. Sadece yıl bilgisi için bkz. Wienerisches Diarium, Supplement zu Num. 30, 15.04.1758; Bergenstamm, Geschichte des unteren Werds, s. 139.

154 OeStA, HHStA, StAbt, Türkei II 34, vr. 36-41. Elçiye ilişkin monografik bir çalışmada heyet mevcudunun sayısı tam verilmez: "[...] Ahmed Resmi appears to have been accompanied by more than sixty people." bkz. Virginia H. Aksan, An Ottoman Statesman in War and Peace: Ahmed Resmi Efendi, 1700-1783, (Leiden: E. J. Brill, 1995), s. 47.

155 OeStA, HHStA, $\ddot{Z Z A} 88$, vr. 1; Wienerisches Diarium, Num. 47, 11.06.1774.

156 OeStA, HHStA, $\ddot{A} Z A$ 88, vr. 87. 


\section{Viyana'da Geçen Zaman}

XVII. yüzyıla kadar diplomatik görevlerinin ifasının ardından şehirden kısa bir zamanda ayrılıp memlekete mümkün olduğunca hızlı dönen Osmanlı elçilik heyetlerinin yerini artık Viyana'da aylarca kalan ${ }^{157}$ kalabalık elçiliklerin alması, evvelde rastlanılmayan yeni hadise ve hikâyelerin yaşanmış olabileceği düşüncesini akla getirir. Orta Avrupa’nın çetin kışşartlarında eksi derecelerdeki soğuğa ve çoğu kez uzun haftalarca diz boyu yüksekliğini muhafaza eden kara, yazın ise yaylalarına çıkıp serinlemek imkânı bulunmayan rakımı 170 m. olan bir düzlükte sıcağa maruz kalmanın dahi Osmanlılar üzerindeki etkisi merak edilebilir. Bundan başka sosyal ve kültürel tarih araştırmalarına zemin hazırlayabilecek daha nice sorunun sorulabileceğini tahmin etmek işten bile değildir. Ne var ki Viyana'ya gelen Osmanlı müellifleri arasında Evliya Çelebi dışında gördüklerini okuyucusunda canlandırmayı çok iyi sağlayan, sosyal yönü kuvvetli, meraklı, nüktedan ve renkli bir şahsiyetin bulunmayışı, bu soruların cevabının bulunmasını ve bunlardan hareketle Osmanlı elçilik heyetlerinin Viyana'da geçirdikleri zamanlarını ortaya koyacak bir metin kompozisyonu inşasını güçleştirir.

Günümüze ulaşmış görece az sayıdaki sefaretnâmeler ve takrirlerse -yazılma sebepleri itibariyle beklenileceği üzere- mezkûr zamana ilişkin ekseriya coğrafî, askerî, ${ }^{158}$ idarî ve siyasî içeriğe sahiptir. Sefaretnâmelerde güzergâh, konaklanan menziller, varılan yerleşim birimleri ve buralardaki halkın tanıtılmasına dair bilgiler bulunabilse de ${ }^{159}$ bu metinler, Osmanlıların Viyana'daki sosyal, hele gündelik hayatlarına dair malumat bakımından fakirdir. Ayrıca günlük tutmanın ve hatırat yazmanın da bir Osmanlı alışkanlığı olmaması, araştırmalar önündeki bir diğer müşküldür. Bu durum, araştırmacıları ister istemez yabancı kaynaklar temelli bir metin inşasına icbar eder. Meselâ elçiler ve yakınındakiler için tabiî ama Avrupalılar için şâyân-ı dikkat olan bir husus, hicrî takvimi kullanan Osmanlıların takvimce belirli dinî hayatı kararlılıkla yaşamasıydı. Ramazan'da oruçluyken -en ufak bir şey dahi!- yiyip içmemeleri, bayramlarda umuma ikramlarda bulunmaları ve çok renkli kutlamalar tertiplemeleri (Ek VII) hem yazılı hem sözlü medyada yankı buluyordu. Osmanlılar namaz ibadetini yerine getirirken de rahat bir tavır

1571645 'te 119, 1650'de 161, 1665'de 279, 1700'de 273, 1719'da 269 gün (Perger ve Petritsch,

"Der Gasthof”, s. 162).

158 Kara Mehmed Paşa’nın elçilik takririnde Beç Kalesi'nin tabya ve hendeklerinin ölçüldüğü anlatılırken, bunlara dair mesafe ve adet bilgileri verilir (Yücel, "Cevâhirü't-Tevârîh", s. 301-305).

159 Beydilli, “Sefâretnâme”, s. 289. 
takınıyorlardı. Süleyman Bey’in ve heyetinden küçük bir maiyetin 17 Temmuz 1774 Pazar akşamı katıldıkları bir tiyatro temsili sırasında kendilerine ayrılmış olan locada sefaret imamıyla birlikte alenen (öffentlich) namaz kıldığı, Viyana gazetesinden (Wienerisches Diarium) şaşılası (sonderbar) haber olarak okunabilmektedir. ${ }^{160}$ Benzeri bir şaşkınlığın Yirmisekiz Çelebi Mehmed'in elçiliği sırasında Paris’te de yaşandığını görmek mümkündür. Mehmed Çelebi ve heyeti, alenen yere serdikleri kilimlerde namaz kılmış ve tesbihlerini genellikle ellerinde bulundurmuştu. ${ }^{161}$

Görüldüğü kadarıyla Osmanlı elçilerinin genellikle Viyana’daki ilk ikinci veya üçüncü haftasında gerçekleştirdikleri -ve dönmeden önce tekrarlayacakları- resmî ziyaretlerden sonra, diplomatik programları yoğun sayılmazdı. Resmî sebepler dışında ikametgâhlarından pek ayrılmadıkları söylenebilir. Bununla birlikte rutin ve kapalı bir hayattan sıkılarak bulundukları kızıl elmada gezintiye çıtıkları da söz konusuydu. Şehir merkezinde dolaştıkları, alışveriş yaptıkları ve bu sırada saray tercümanı aracılığıyla pazarlık da edildiği bilinmektedir. Ancak özellikle iki yer, Batılıların ilgisini çektiğinden daha fazla, incelikli bir bahçe kültürüne sahip Osmanlıların ilgisini çekerdi: geniş alana yayılmış botanik zenginliğe sahip varoşların saray bahçeleri ve doğa. ${ }^{162}$ Kara Mehmed Paşa’nın elçiliği sırasında elçilikten sorumlu saray tercümanı Franz von Mesgnien-Meninski'nin kaleme aldığı bir rapor, elçinin Ekim 1665 teki bir doğa gezisini detaylı bir şekilde anlatır. ${ }^{163}$ Buna göre o sırada elçilikten sorumlu komiser olan Lorenz von Churelitz, elçiye meşhur Kahlenberg'e (Eski Beç) ${ }^{164}$ gezmeye gidilebileceği teklifinde bulunmuştu. Türlü aksiliklere rağmen sonunda Kahlenberg'e varılsa da, 423 metredeki zirveye çıkılması yine Churelitz tarafından -Meninski'den sonra kaleme aldığı kendi raporuna göre-Türklerin coğrafyayı iyi tanımasına imkân tanımamak için engellenmişti. ${ }^{165}$

Habsburg ricâli, şehirlerinde bulunan Osmanlı elçilerini zaman zaman çeşitli etkinlik ve eğlencelere davet ederek ihtişam ve kültürlerini göstermeyi amaçla-

160 Wienerisches Diarium, Num. 58, 20.07.1774.

161 Işıısel, "Yirmisekiz Çelebi Mehmed”, s. 103.

162 Teply, "Türkische Gesandtschaften”, s. 23-24.

163 "Relazione di ciò che é passato circa l'ambasciata solenne turchesca nell'anno 1665 e 1666" isimli bu rapor Hanedan, Saray ve Devlet Arşivi'nde yazma nüsha hâlinde bulunmaktadır (Markus Köhbach, “Der Reflex einer Wiener Lokalsage bei Evliya Çelebi?” Osmanlı Araşttrmalar, XI (1991), s. 230 dipnot 5).

164 Bilindiği üzere Kahlenberg, II. Viyana kuşatması sırasında bozgunun yaşandığı yerdir (12 Eylül 1683).

165 Köhbach, “Der Reflex einer Wiener Lokalsage”, s. 230-231. 
mışlardı. Belki burada da mütekabiliyeti sağlama gayretinden bahsedilebilir. Zira bilindiği üzere İstanbul'a gelen Habsburg fevkalâde elçileri, sadrazam başta olmak üzere devlet ricâli tarafından Haliç ve Boğaz'da bulunan çeşitli saray, kasır veya yalıya davet edilir, onlara ziyafet verilirdi ${ }^{166}$ ve bu davetler, Habsburgların ilgi ve beğenilerini ortaya koyan elçilik raporlarında ayrıntılı bir tasvirle yer bulurdu. ${ }^{167}$ Viyana'da da büyükelçilerin, kayzerin ve validesinin saray bahçelerinde tertiplediği ziyafetlere katılmaları, opera ve komediye ta'bir olunur hayâl-hânelere ${ }^{168}$ gitmeleri söz konusu olmuştu. ${ }^{169}$ Ayrıca kızak kaymaya, ava, maskeli balolara, karnavallara, müzikallere, bale ve havaî fişek gösterilerine katıldıkları bilinmektedir. ${ }^{170}$

XVIII. yüzyıla gelindiğinde Avrupa'da Osmanlılara yönelik ilgi, geçmiş yüzyıllara kıyasla önemli bir değişime uğramıştı. Artık yazarlar Osmanlı tarihine dair analizlerde bulunmak, Osmanlı idarî yapısını ve toplumunu ele almaktan uzaklaşmıştı. ${ }^{171}$ Zaten bu tür anlatıların alıcısını bulmak da pek mümkün olmazdı. Zira bilindiği üzere Osmanlıların giyim kuşamı, yeme içmeleri, renkleri hatta müzikleri, hareketli biçimde barok çağını yaşayan Avrupa’da ilham kaynağı olacak ve Türk modasını başlatacaktı. Memleketlerine gelen yüzlerce kişiden oluşan bu "egzotik" misafirler, kayzerden başlamak üzere çevresindeki asiller ve kentsoylulardan şehir halkının en alt zümresine kadar geniş bir kitlenin büyük ilgisini uyandırırdı. Hele mezkûr modanın ikonları kendi memleketlerine geldiğinde, onlarla tanışma fırsatını değerlendirmek isteyenler çoktu. Ayrıca konukların mutlaka diplomat vasfını taşıması gerekmezdi. Denilebilir ki bin bir gece masalları, or-

166 Kütükoğlu, "XVIII. Yüzyılda Osmanlı”, s. 225.

167 Bir örnek için bkz. Gerard Cornelius von den Driesch, Historische Nachricht von der Röm. Kayserl. GroßBotschafft nach Constantinopel, welche auf allergnädigsten Befehl Sr. Röm. Kayserlichen und Catholischen Majestät Carl des Sechsten [...], (Nürnberg: Peter Conrad Monath, 1723), çeşitli yerleri.

168 Şem'dânîzâde Fındıklılı Süleyman Efendi, Şem'dânîzâde Fındıklılı Süleyman Efendi Tarihi: Müri't't-Tevârih, c. II/A, haz. Münir Aktepe, (İstanbul: İstanbul Üniversitesi Edebiyat Fakültesi Yayınları, 1978), s. 22.

169 Hangi eserleri izledikleri, Wienerisches Diarium'dan takip edilebilmektedir. Bu konuda yapılmış bir çalışma için bkz. Suna Suner, "Of Messengers, Messages and Memoirs: Opera and the Eighteenth-Century Ottoman Envoys and Their Sefâretnâmes", Ottoman Empire and European Theatre, vol. II: The Time of Joseph Haydn: From Sultan Mahmud I to Mahmud II (r. 1730-1839), eds. Michael Hüttler, Hans Ernst Weidinger, (Wien: Hollitzer Wissenschaftsverlag, 2014), s. 83-143.

170 Teply, "Türkische Gesandtschaften”, s. 25.

171 Çırakman, From the "terror of the world", s. 106. 
yantalist roman ve seyahatnamelerle beslenmiş romantik Doğu kültürü imajı Osmanlı temsilcilerinde vücut buluyordu. Türk modasından çok öncesinde de elçilerin Viyana'da akredite edilmiş yabancı misafirleri kabul ettikleri bilinmekle beraber bilhassa XVIII. yüzyılın başından itibaren Osmanlı elçileriyle vicâhen görüşmeyi -elçilerin vardığı daha ilk günlerden beri-arzulayan kadınlı erkekli bir zümrenin âdeta sırada beklediği söylenebilir. ${ }^{172}$

1719 Ağustos'unda İbrahim Paşa henüz Viyana önlerinde bulunup şehre girmemişken huzura kabul edilen Prusyalı maceraperest Baron von Pöllnitz, büyükelçiyle görüşmesine dair hatıralarını detaylı bir şekilde kaleme almışı. Anlatılana göre Türingiyalı Alman soylu birkaç arkadaşıyla birlikte büyükelçinin çadırının önünde oldukça nazik bir şekilde ağırlandı, kendisine kahve ve şekerlemeler ikram edildi ve biraz sohbetten sonra eğer isterse kampı dolaşabileceği teklif edildi. Nazik teklifi kabul eden barona bir rehber verildi ve baron iki bin kişiyi barındırabilecek kadar büyük kampın çadırları arasında dolaştıktan sonra arkadaşlarıyla birlikte oradan ayrıldı. ${ }^{173}$ Avrupa'daki Türk modasının zirve yapacağı XVIII. yüzyılın ortalarında Büyük Friedrich'in (1740-1786) sarayında ömrünün son zamanlarını geçiren von Pöllnitz'in, İbrahim Paşa’nın Viyana şehrine 763 kişilik heyetiyle mutantan girişinin görgü şahidi olarak da anlatacak çok şeyi olmuştu.

Bambaşka bir kültür ve din coğrafyasındaki farklılıklara dair merak oluşmasının her hâlde her millet için geçerli olması gibi, "Kâfirlerin cenneti" olan dünyanın cazibesi ve eğlencesi, bu Hıristiyan diyarda hiç olmadığı kadar uzun müddet kalan kalabalık Osmanlı elçilik heyetlerindeki görevlilerin de -hiç değilse bir kısmının- iştahını kabartmış olabilir. Memleketlerinden ve ailelerinden yüzlerce kilometre uzakta, türlü zahmetlere katlanan seferîlerde baş gösterebilecek bu iştahın kontrol altında tutulması için, zaman zaman gerekli tedbirlerin alındığının varsayılması da doğru olacaktır. Ne de olsa sultan, devlet ve İslâm temsil edilmekteydi.

Ancak kontrolün her zaman sağlanamadığ 1 ve düzeni sürdüren ölçülerin gerektiğinde sert önlemlerle hatırlatılması gerektiği, insan unsuru hesaba katıldığında tabiî olarak varsayılabilir. Çağdaş Felemenk hukukçu Cornelius van

172 Perger ve Petritsch, "Der Gasthof”, s. 168.

173 Ayrıntılar için bkz. Karl Ludwig von Pöllnitz, The Memoirs of Charles-Lewis, Baron de

Pollnitz: Being the Observations He Made [...], vol. IV, (London: Daniel Browne and John Brindley, 1745), s. 61-66. 
Bynkershoek'e bakılırsa, bunu gösteren bir örnek 1700 yılında 520 kişiden müteşekkil bir heyetle Viyana'da bulunmuş olan İbrahim Paşa’nın elçiliği s1rasında yaşanmıştı. O sırada nüfusu 100.000 'e ulaşmış olduğu tahmin edilen ${ }^{174}$ ve dükkânları geç saate kadar açık kalan bu canlı Avrupa metropolü, elbette merak uyandırabilecek çok sayıda mekâna sahipti. Kendilerini bu meraka kaptıran kapı halkından birçok kişinin içki içip sarhoş olması, üstüne bir de asayişi bozup rezalet çıkarması büyükelçinin kulağına gitmişti. Neticede paşa, bu tatsız olayın sorumlularından birini ibret-i âlem için ikametgâhının önündeki bir ağaca astırıp, diğerlerine de ellişer sopa attırmıştı. ${ }^{175}$ Belki suçu hafifletici sebepler de yok değildi. Zira büyükelçinin Pasarofça Antlaşması'nın tasdiknâmesini getiren adaşının elçiliği üzerine kaleme alınmış sefaretnâmede anlatılana göre, o sırada Nemçe topraklarında yapılan yolculuğun henüz ilk önemli durağı olan Belgrad'da "[...] Tuna semtindeki evleri ve dükkânları bütün meyhâne etmişler [...]." 176

Sonuç olarak, Avusturya Devlet Arşivlerinin Osmanlı elçilik heyetlerine dair sahip olduğu belgeler ve Habsburg merkez teşkilâtının ilgili kurumları üzerinde yapılan incelemeler ışığında Habsburgların Osmanlıları ağırlama sürecinde sefaretlerin Viyana'ya doğru gelişlerinden İstanbul'a dönüşlerine kadar geçerli olduğu görülen teâmül çerçevesinde iş bölümü ilkesiyle hareket edildiği, görev dağıtımında meslekî kariyerleri ve tecrübesi olan kıdemli kişilerin seçildiği ortaya çıkmaktadır. Ayrıca İstanbul'a gönderilmiş Habsburglu elçilerin Osmanlılar tarafından nasıl ağırlandıkları gibi birçok mesele dikkate alınmak suretiyle, Osmanlılarla diplomatik zeminin hemen her alanında mütekabiliyetin sağlanmaya çalışıldığı açıktır. Osmanlı diplomasi tarihine bakıldığında Devlet-i Aliyye çok sayıda elçiyle uzun yıllar Viyana'da temsil edildiğinden, buradaki tecrübenin tafsilatlı bir şekilde bilinmesi, bu tarihe dair bütüncül çıkarımlarda bulunmak için elzemdir. Her ne kadar Osmanlı kaynakları bu tecrübeyi etraflıca yansıtma noktasında yetersiz olsa da, Avusturya Devlet Arşivleri başta olmak üzere hayli ilginç bilgiler sunduğu görülen birçok çağdaş yabancı kaynak, resmin tamamını göstermeye yardımcı olacaktır.

174 Winkelbauer, Österreichische Geschichte 1522-1699, s. 21.

175 Cornelis van Bijnkershoek, Traité du Juge competent des Ambassadeurs, tant pour le Civil, que pour le Criminel; Traduit du Latin par Jean Barbeyrac (Den Haag, La Haye: Thomas Johnson, 1723), s. 243.

176 Kraelitz-Greifenhorst, "Bericht über den Zug”, s. 26. 
Öz — Budin'in 1541'de eyalet olarak Osmanlı topraklarına katılmasıyla birlikte Osmanlılarla Avusturya Habsburgları birbiriyle komşu olmuş ve Zitvatorok Antlaşması (1606) ile iki gücün arasındaki diplomatik trafik artmıştı. Geçmişi XV. yüzyılın sonlarına uzanan Osmanlı-Habsburg diplomatik tarihi üzerinde araştırmalar yapıldığında, başvurulması gereken ana kaynaklardan birisi Avusturya Devlet Arşivleridir. Arşivlerde siyasî önemi haiz belgelerin yanında Viyana’da misafir olarak bulunmuş ve sayıları XVII. ve XVIII. yüzyıllar arasında büyük artış göstermiş Osmanlı elçiliklerinin ağırlanma sürecini aydınlatma vasfına sahip çok sayıda belge bulunur. OsmanlıHabsburg askerî mücadelesini kesin olarak nihayete erdiren Ziştovi Antlaşması'na (1791) kadar Viyana'ya yaklaşık doksan Osmanlı elçilik heyeti gönderilmiştir. Bu çalışmada, 1634-1774 yılları arasını kapsayan dönemde gönderilmiş elçiliklerin Habsburg kurumlarınca ne şekilde, nerede ağırlandıkları ve ağırlamadan kimlerin sorumlu olduğu soruları üzerinde durulmuştur. Bu makalede, şimdiye kadar ortaya konmuş veriler Avusturya Devlet Arşivlerinde bulunan belgelerin bir kısmını kullanmak suretiyle elde edilen yeni bulgularla birleştirilerek, Osmanlı elçilik heyetlerini merkeze alarak Osmanlı-Habsburg diplomasi tarihine dair bir inceleme yapılmaya çalışılmıştır.

Anahtar kelimeler: Osmanlı, Habsburg, Osmanlı elçilik heyetleri, diplomasi, ikametgâh, idarî tarih, Viyana, XVII.-XVIII. yüzyıllar, Avusturya Devlet Arşivi. 
Ek I: 1692'deki Tuna'yı, Viyana'yı ve varoşlarını gösteren haritadan bir kesit Guillaume Sanson, Plan de la Ville de Vienne et ses Environs, Paris: Jaillot, 1692.

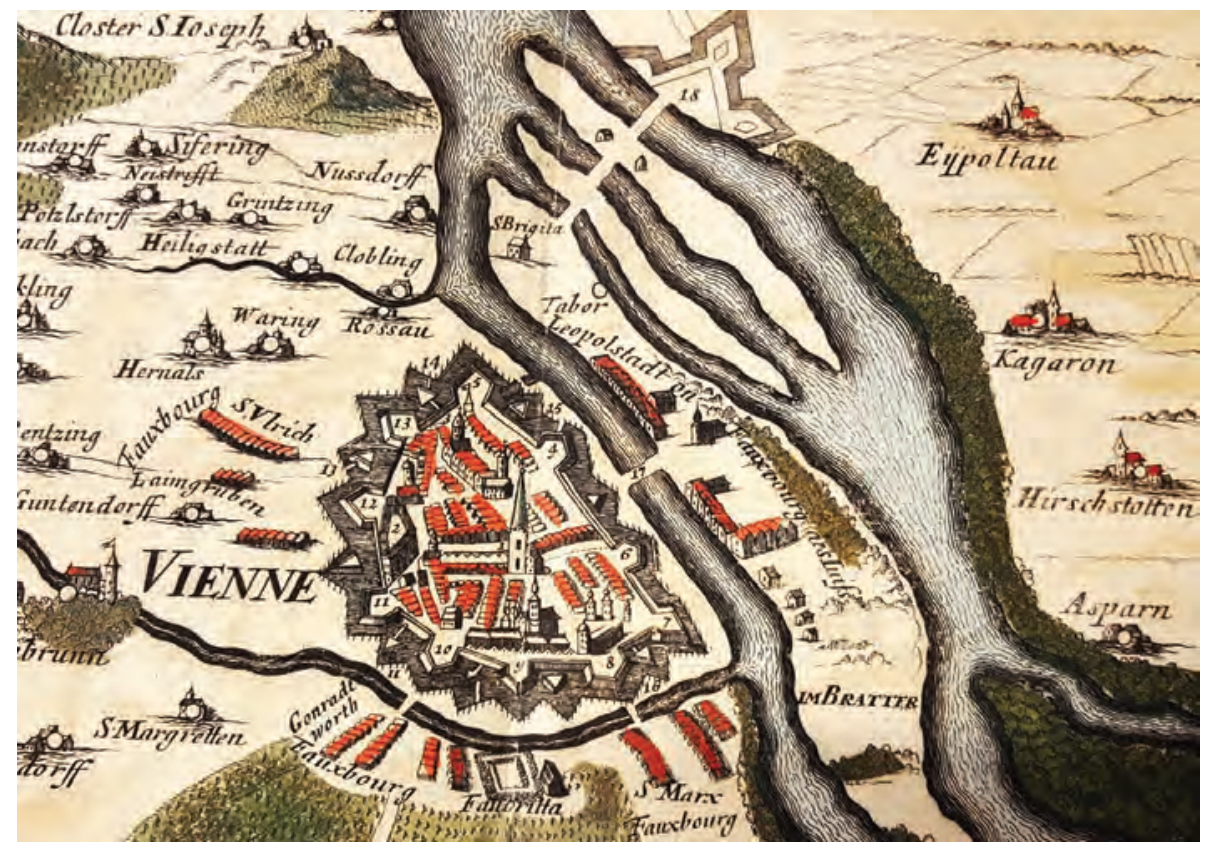

Ek II: Leopoldstadt'ı gösteren bir gravür (Haritanın en alt kısmının ortasında meşhur Schlagbrücke görünür)

Ignatiu Schachner, Lustra Decem Corona Viennensis [...], Wien: Ghelen, 1734, s. 9.

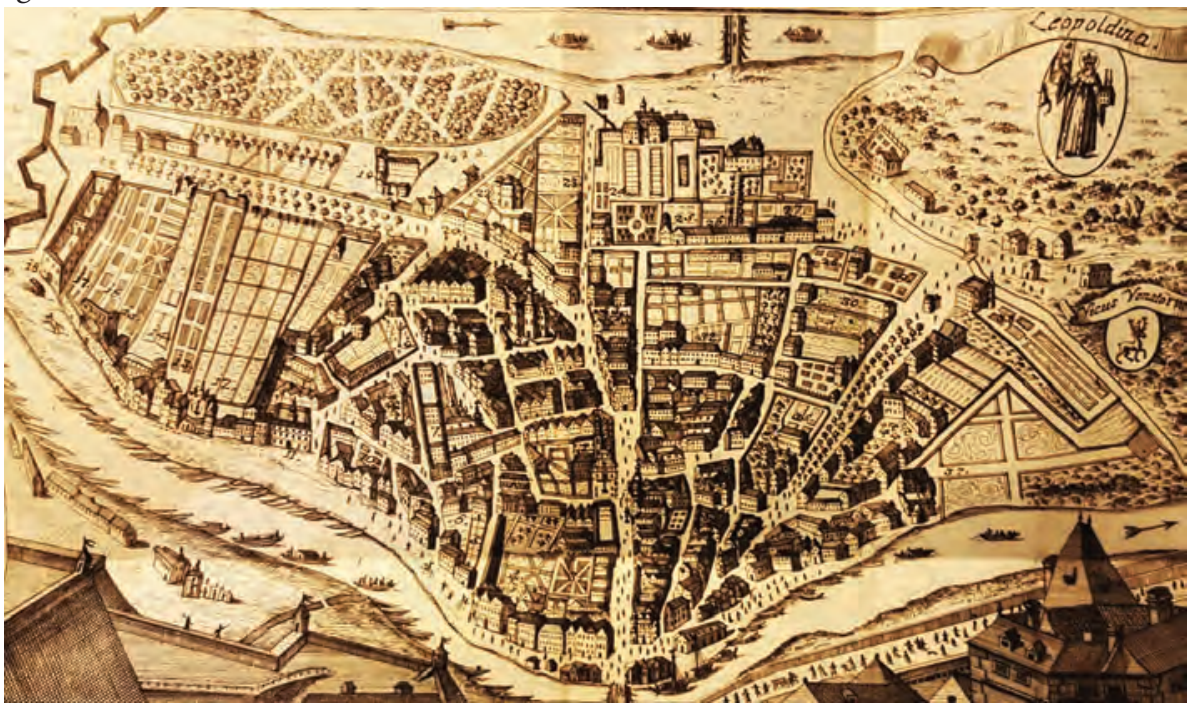




\section{Ek III: Seyfullah Ağa’nın Prens Eugen tarafından resmikabulü}

J. B. Fischer von Erlach, Entwurff einer Historischen [...], Leipzig: F. von Erlach, 1725, Nr. V.

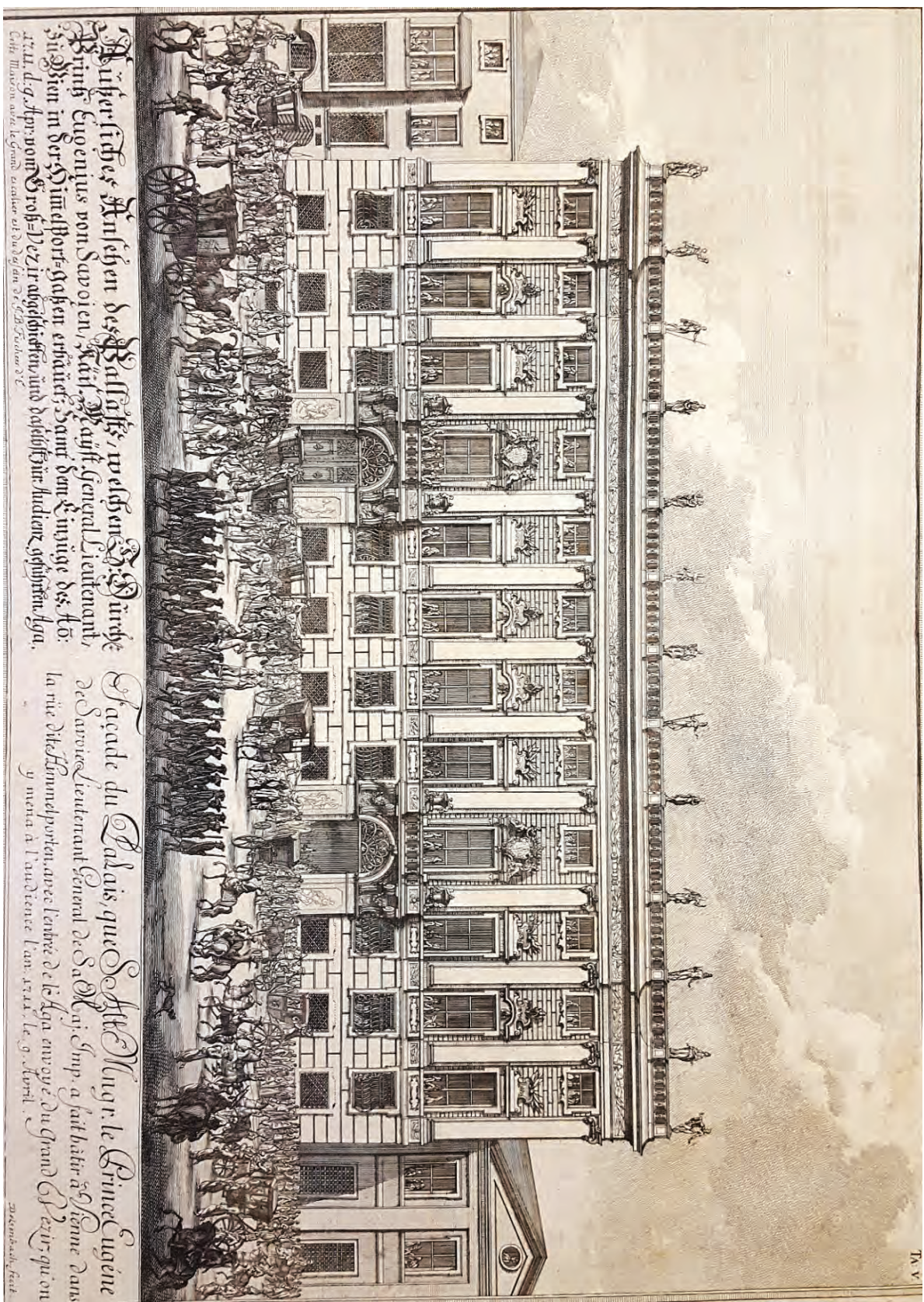


HÜSEYİN ONUR ERCAN

Ek IV: Zum Goldenen Lamm binasının 1758 yılına ait zemin katı planı OeStA, FHKA SUS KS, Rb-221/2.

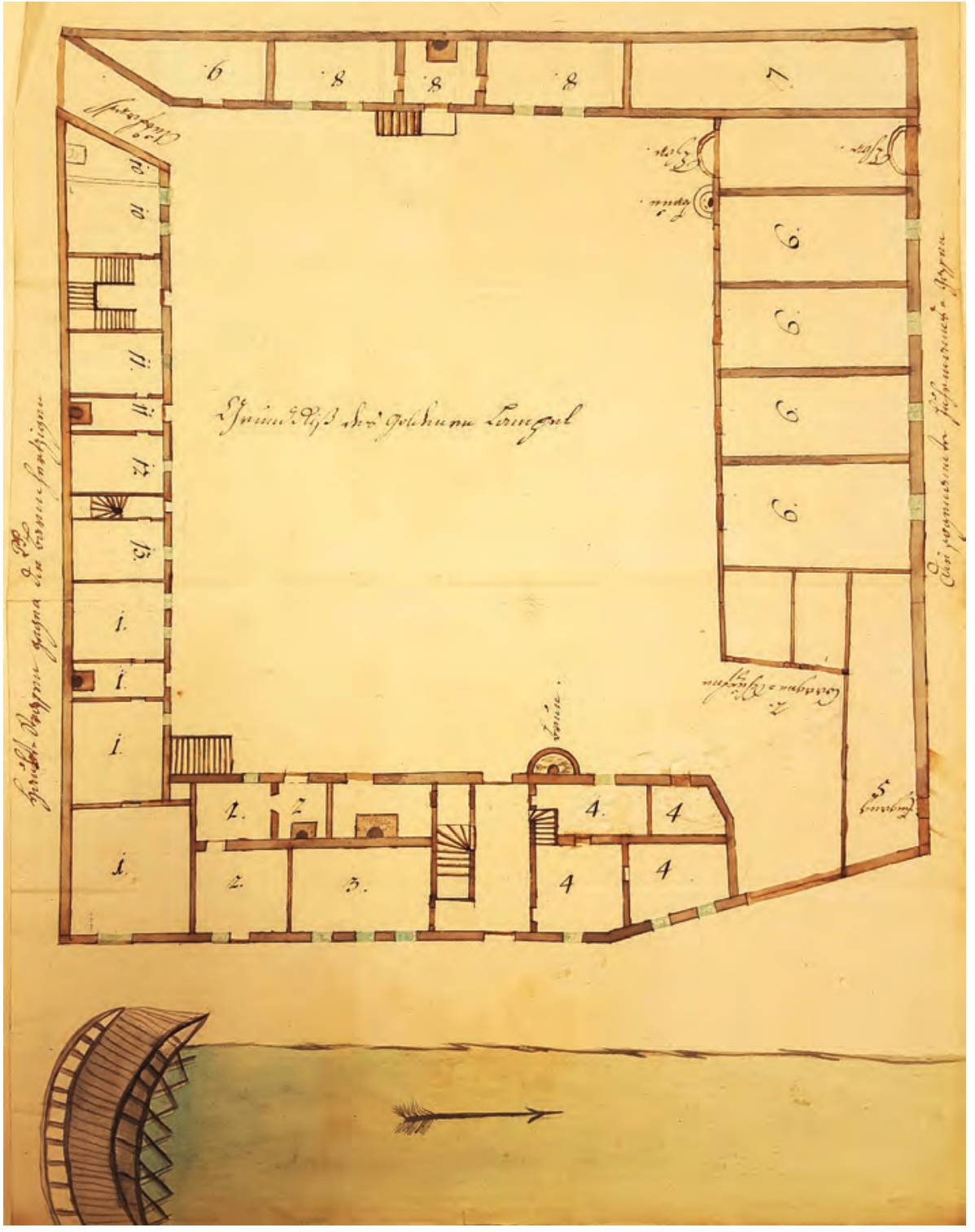


OSMANLI ELÇİLIKK HEYETLERINIIN AVUSTURYA DEVLET ARŞİVINDEKİ İZLERİ

Ek V: Zum Goldenen Lamm binasının 1758 yilına ait üst kat planı

OeStA, FHKA SUS KS, Rb-221/1.

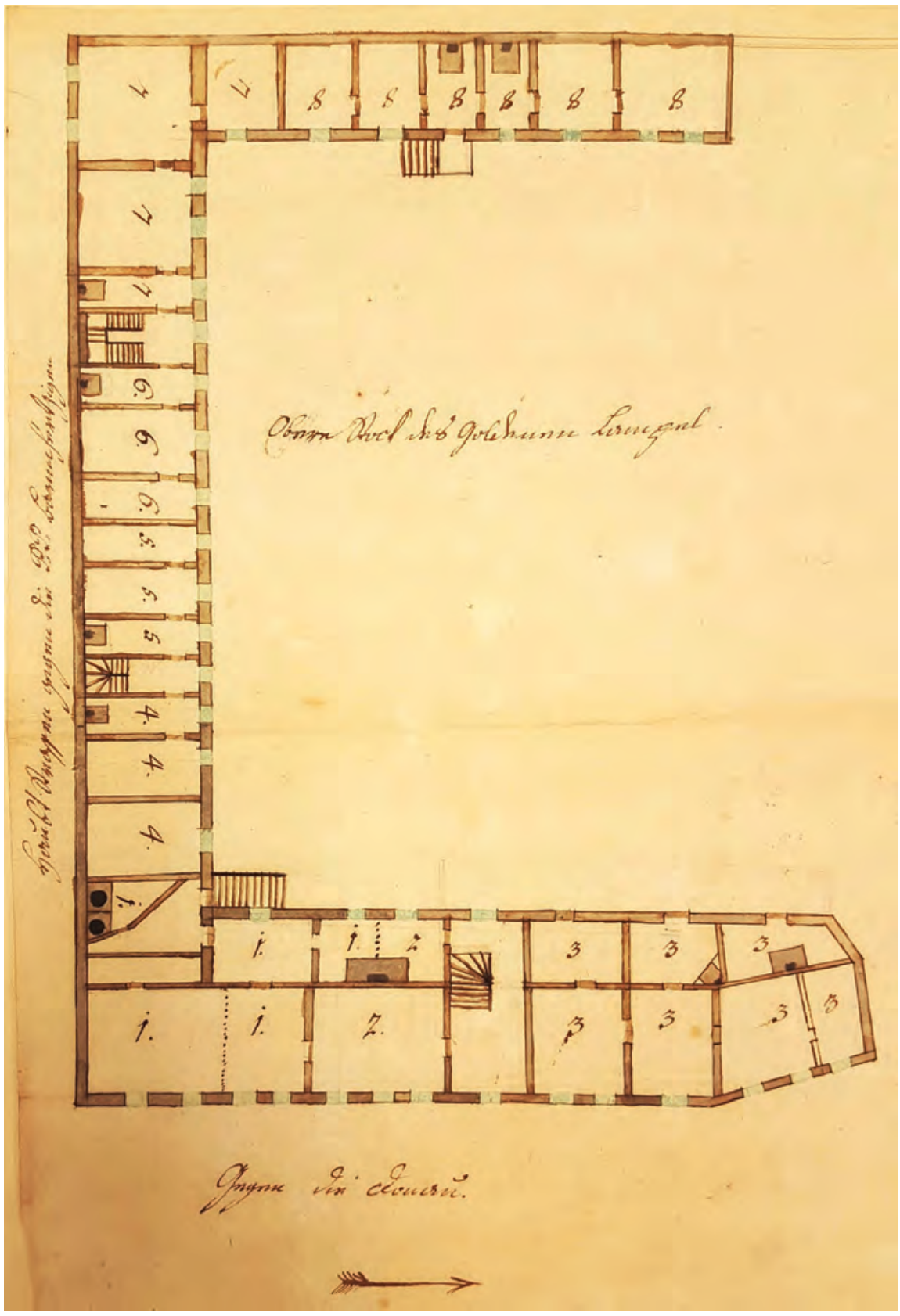


Ek VI: Zum Goldenen Lamm'da 1700'deki divân merasimini tasvir eden bir gravür Schönwetter, Gründ- und umständlicher [...], s. 59; Perger ve Petritsch, "Der Gasthof”, s. 161.

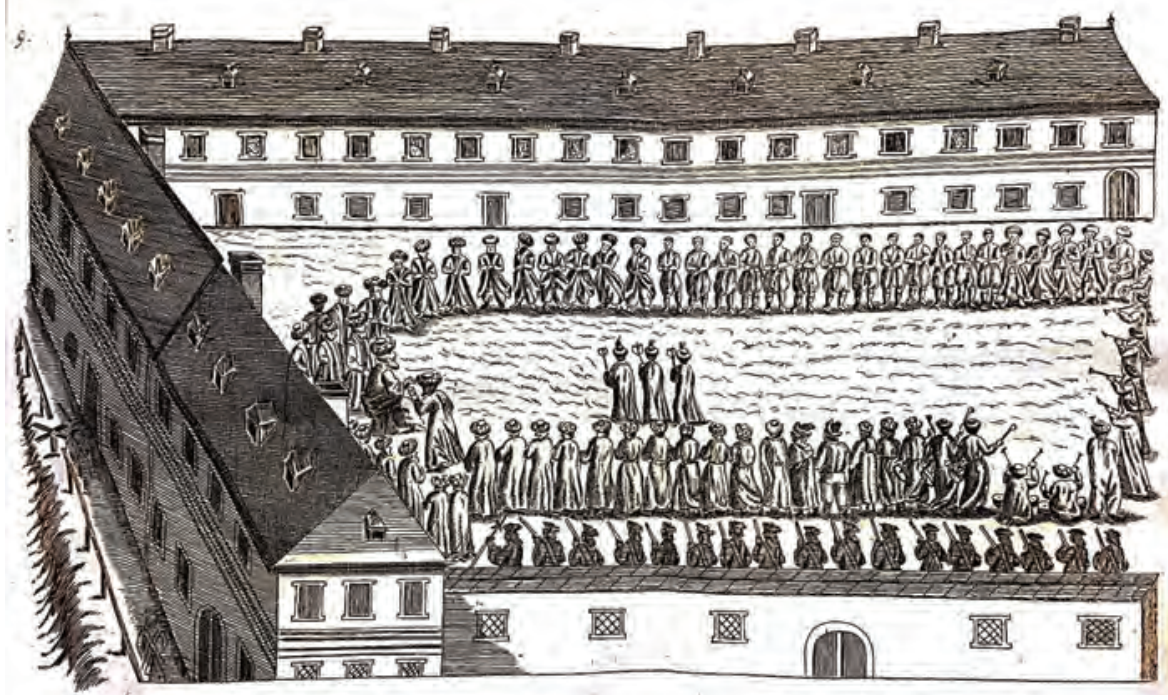

Ek VII: Zum Goldenen Lamm'da Mart 1700'deki bayram eğlencesini tasvir eden bir gravür

Schönwetter, Gründ- und umständlicher [...], s. 77; Perger ve Petritsch, "Der Gasthof”, s. 170.

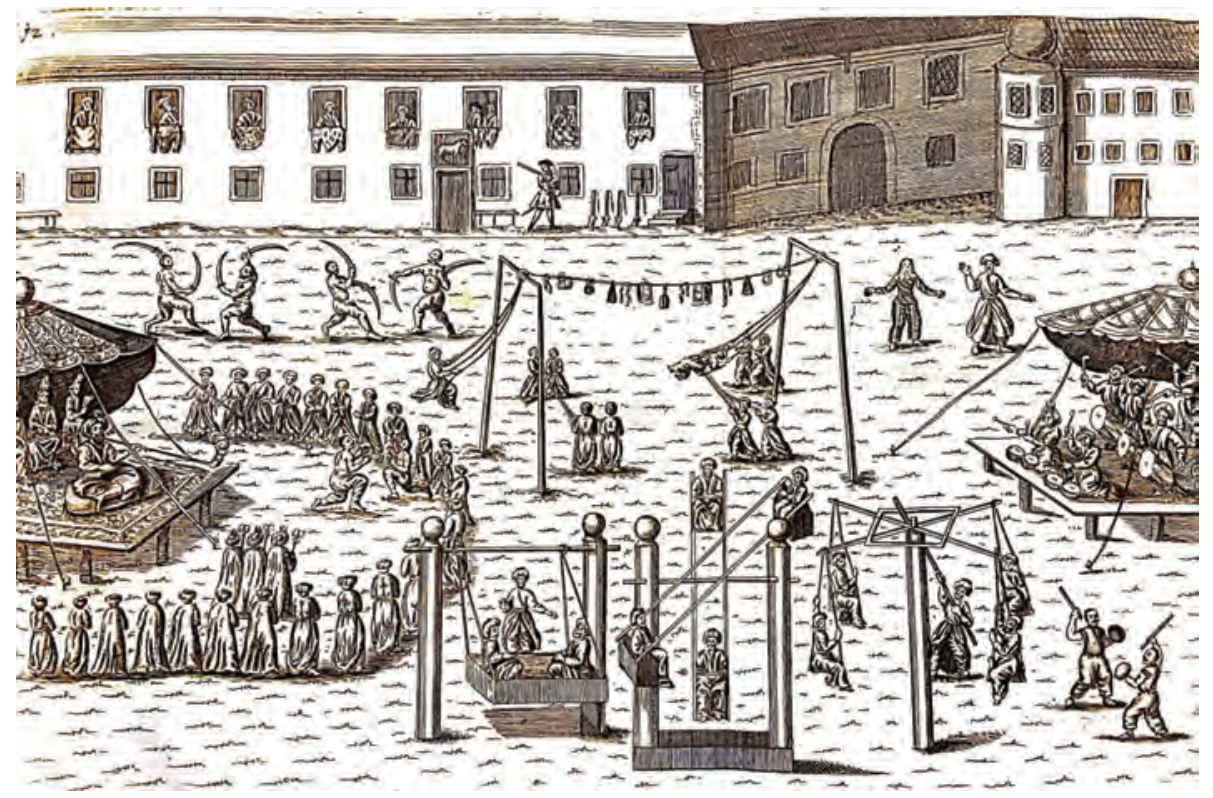


Ek VIII: Saray Harp Şûrası'ndan Maliye Dairesi'ne, Müteferrika Ahmed Ağa'nın komiser tarafından kötü muamele gördüğüne dair şikâyetini aktaran 8 Mayıs 1636 tarihli resmî yazı

OeStA, FHKA, Reichsakten, Fz. 303.5, vr. 1.

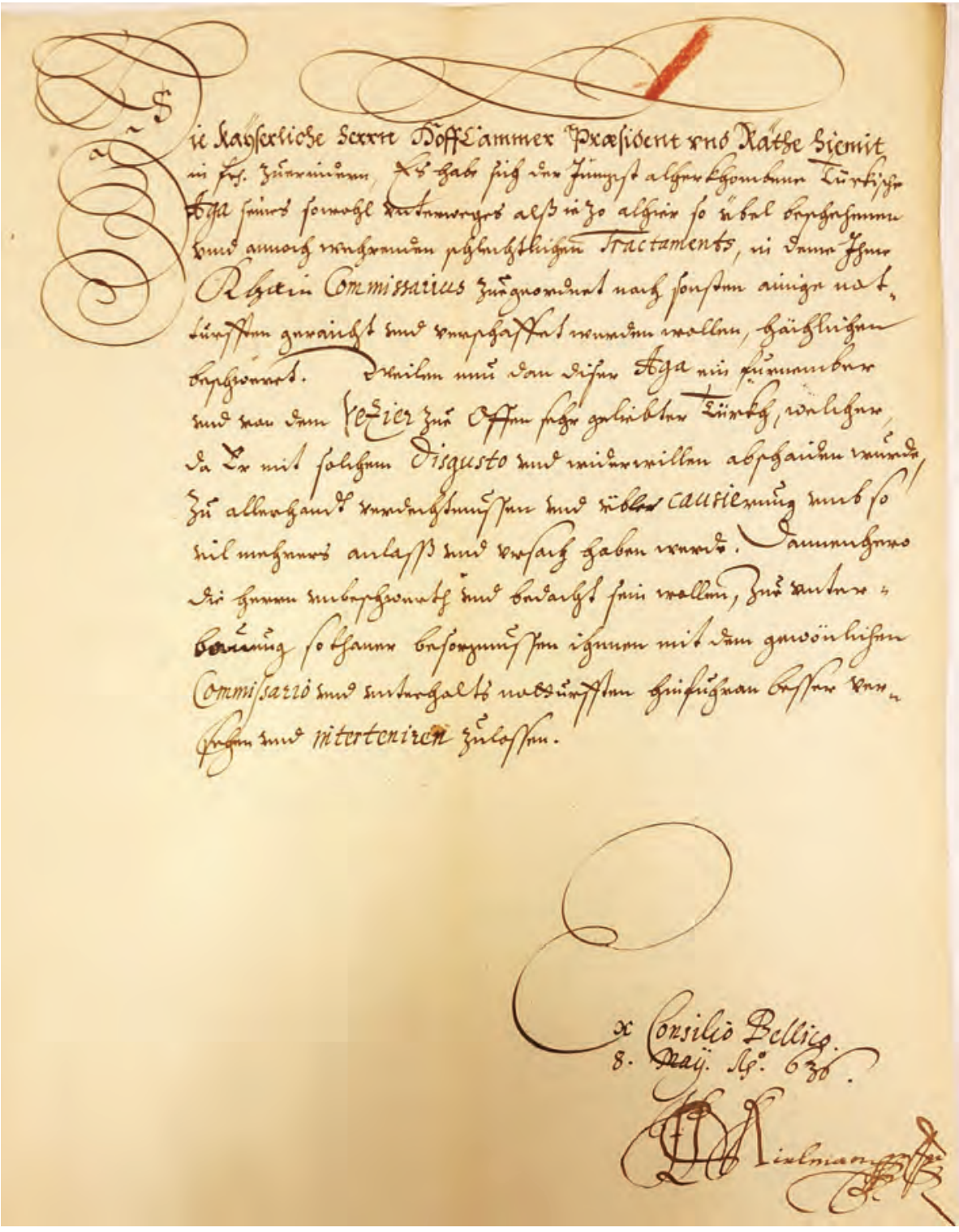




\section{Bibliyografya}

\section{Arşiv Belgeleri}

Österreichisches Staatsarchiv (OeStA)

Finanz- und Hofkammerarchiv (FHKA),

Reichsakten, Faszikel (Fz.) 277.38, vr. 278; 278.38, vr. 185-186; 280.20, vr. 9; 302.63, vr.2; 303.5 , vr. 1 ; 303.29 , vr. 8 ; 304.2 vr. $75,80,112 / 1,123$; Fz. 306.14, vr. 336; 307.6, vr. 8, 28.

Sammlungen und Selekte (SUS), Karten- und Plansammlung (KS), Rb-221/1, 2.

Kontrakte und Reverse, C-1373

Haus-, Hof- und Staatsarchiv (HHStA),

Ältere Zeremonialakten (ÄZA) 6-22 vr. 29; ÄZA 6-23 vr. 2; ÄZA 20-38 vr. 170; ÄZA 35 vr. 8; ÄZA 50 vr. 8; ÄZA 51, vr. 5; ÄZA 88 vr. 1, 87.

Staatenabteilung (StAbt), Türkei I 113, vr. 71; Türkei II 34, vr. 36-41.

Zeremonialprotokolle 10 (1717-1719), vr. 367.

Kriegsarchiv,

Hofkriegsrat Protokolle 1028, 58/5.

\section{Gazeteler}

Wienerisches Diarium, Num. 1675, 19.08.1719; Num. 43, 30.05.1731; Num. 63, 06.08.1740; Extra-Blatt zu Num. 41, 22.05.1748; Supplement zu Num. 30, 15.04.1758; Num. 47, 11.06.1774; Num. 58, 20.07.1774.

\section{Yayımlanmış eserler}

Ahmed Resmi Efendinin Viyana ve Berlin Sefaretnameleri, (haz.) Bedriye Atsız, İstanbul: Tercüman 1980.

Aksan, Virginia H.: An Ottoman Statesman in War and Peace: Ahmed Resmi Efendi, 17001783, Leiden: E. J. Brill 1995.

Aydıner, Mesut: "Mustafa Efendi, Tavukçubaşı Damadı", TDV İslâm Ansiklopedisi, EK-II (2016), s. 326-328.

Balbous, Cécile: Das Sprachknaben-Institut der Habsburgermonarchie in Konstantinopel, Berlin: Frank \& Timme 2014.

Bayerle, Gustav: The Hungarian letters of Ali Pasha of Buda: 1604 - 1616, Budapest: Akad 1991.

Bergenstamm, Alois Groppenberger von: Geschichte des unteren Werds, oder der heutigen Leopoldstadt: aus Urkunden gezogen, Wien: Kaiserl. königl. Hof- und Staatsdruckerey 1812. 
Beydilli, Kemal; Erünsal, İsmail E.: "Prut Savaşı Öncesi Diplomatik Bir Teşebbüs: Seyfullah Ağa’nın Viyana Elçiliği (1711)”, TTK Belgeler, XXII/26 (2002), s. 1-183.

Beydilli, Kemal: "Sefaret ve Sefaretnâme Hakkında Yeni Bir Değerlendirme", Osmanlı Araşttrmalart, 30 (2007), s. 9-30.

.: "Sefâretnâme", TDV İslâm Ansiklopedisi, XXXVI (2009), s. 289-294.

Bijnkershoek, Cornelis van: Traité du Juge competent des Ambassadeurs, tant pour le Civil, que pour le Criminel; Traduit du Latin par Jean Barbeyrac, Den Haag: La Haye: Thomas Johnson 1723.

Czerny, Albin: Ein Tourist in Oesterreich während der Schwedenzeit. Aus den Papieren des Pater Reginbald Möhner, Linz: Ebenhöch 1874.

Ç1rakman, Aslı: From the "terror of the world" to the "sick man of Europe": European images of Ottoman Empire and society from the sixteenth century to the nineteenth, New York [et al.]: Peter Lang 2002.

Dávid, Géza: "Budin”, TDV İslâm Ansiklopedisi, VI (1992), s. 344-348.

Driesch, Gerard Cornelius von den: Historische Nachricht von der Röm. Kayserl. GroßBotschafft nach Constantinopel, welche auf allergnädigsten Befehl Sr. Röm. Kayserlichen und Catholischen Majestät Carl des Sechsten [...], Nürnberg: Peter Conrad Monath 1723.

Emecen, Feridun M.: "Çağdaş Osmanlı Kaynaklarında Uzun Savaşlar ve Zitvatorok Antlaşması ile İlgili Algılama ve Yorum Problemleri”, Osmanlı Araştırmaları, 29 (2007), s. $87-97$.

Ercan, Hüseyin Onur: Osmanlı-Habsburg Diplomasisi: Rudolf Schmid'in Nihâ̂ Raporunun Türkçeye Çevirisi ve Otuz Yıl Savaşlarıyla İlişkisi (1629-1643), (Yayımlanmamış Yüksek Lisans Tezi) İstanbul: İstanbul Üniversitesi, 2013.

Evliya Çelebi b. Derviş Mehemmed Zillî: Evliyâ Çelebi Seyahatnâmesi, 7. Kitap: Topkapı Sarayı Kütüphanesi Băgdat 308 Numaralı Yazmanın Transkripsiyonu-Dizini, haz. Yücel Dağlı, Seyit Ali Kahraman, Robert Dankoff, İstanbul: Yapı Kredi Yayınları 2003.

Eyice, Semavi: "Elçi Hanı", İstanbul Üniversitesi Edebiyat Fakültesi Tarih Dergisi, 24 (1970), s. 93-130.

Fellner, Thomas: "Zur Geschichte der österreichischen Centralverwaltung (1493-1848) I. Bis zur Errichtung der österreichischen Hofkanzlei”, Mitteilungen des Instituts für Osterreichische Geschichtsforschung, 8 (1887), s. 258-301.

Fellner, Thomas ve Kretschmayr, Heinrich: Die österreichische Zentralverwaltung, I. Abt.: Von Maximilian I. bis zur Vereinigung der Österreichischen und Böhmischen Hofkanzlei (1749), c. I, Wien: Adolf Holzhausen 1907.

Fischer von Erlach, Johann Bernhard: Entwurff einer Historischen Architectur in Abbildung unterschiedener berühmten Gebäude, des Alterthums und fremder Völcker [...], 4. Buch, Leipzig: Johann Bernhard Fischers von Erlachen 1725.

Friedens Conditiones, wie dieselben zwischen dem Römischen vnnd Türckischen Keyser, Rudolpho dieß Namens dem andern, vnd Hehomath Sultan dem ersten, Im Feldlager zwischen der 
Thonaw vnnd Sitwa in Hungern, abgehandelt vnnd beschlossen, (Prag: Johan Ottmari Jacobi, 1607 [Mit Bewilligung Nachgedruckt zu Nürnberg durch Christoff Lochner, 1607]).

Gévay, Anton: A' budai pasak, Bécsben: Strauss Antal 1841.

Gezer, Ömer: "1522'den 19. Yüzyıla Kadar Habsburg Mutlakıyetinin İnşası ve Militärgrenze”, Avrupa Tarihinde Türk Eli Doç. Dr. Gümę̧ Karamuk Armağanı, haz. Ramazan Acun, Serhat Küçük, Ankara: Hacettepe Üniversitesi Yayınları 2017, s. 137-157.

Gibs, Helga: Leopoldstadt: kleine Welt am großen Strom, Wien: Mohl 1997.

Groß, Lothar: Die Geschichte der Deutschen Reichshofkanzlei von 1559 bis 1806, Wien: Selbstverlag des Haus-, Hof- u. Staatsarchivs 1933.

Hammer, Joseph von: Des osmanischen Reichs Staatsverfassung und Staatsverwaltung, dargestellt aus den Quellen seiner Grundgesetze,c. II: Die Staatsverwaltung, Wien: Camesina 1815.

.: Geschichte des Osmanischen Reiches, I-X, Pest: C. A. Hartleben's Verlage 1827-1835.

Harrach, Ernst Albrecht von: Die Diarien und Tagzettel des Kardinals Ernst Adalbert von Harrach (1598 - 1667). Band 5: Tagzettel 1644-1654, hg. von Katrin Keller und Alessandro Catalano, Wien [u.a.]: Böhlau 2010.

Işıksel, Güneş: "Yirmisekiz Çelebi Mehmed Fransảda: Güzergâh, toplumsal algı, diplomatik pratikler ve de "Lâle Devri”", Doğu Batı Dǚsünce Dergisi, 21 (2018), s. 99-112.

Jobst, Wolfgang: Der Gesandtschaftsbericht des Zülfikâr Efendi über die Friedensverhandlungen in Wien 1689, (Yayımlanmamış Doktora Tezi) Wien: Universität Wien, 1980.

Klesl, Wolfgang: Leopold von Talman: ein österreichischer Diplomat des Spätbarocks, (Yayımlanmamıs Doktora Tezi) Wien: Universität Wien, 1967.

Kisch, Wilhelm: Die alten Strassen und Plätze von Wien's Vorstädten und ibre historisch interessanten Häuser: ein Beitrag zur Culturgeschichte Wiens mit Rücksicht auf vaterländische Kunst, Architektur, Musik und Literatur, I. Band, Wien: Verlag von Oskar Frank's Nachfolger 1888.

Kołodziejczyk, Dariusz: Ottoman-Polish diplomatic relations (15th - 18th century): an annotated edition of Ahdnames and other Documents, Leiden [u.a.]: Brill 2000.

Köhbach, Markus: "Çasar veya İmparator: Jitvatorok Antlaşması'ndan (1606) sonra Roma kayserleri'nin Osmanlılar tarafından telakkubu hakkında", çev. Yusuf A. Aydın, İstanbul Universitesi Edebiyat Fakültesi Tarih Dergisi, 37 (2002), s. 159-169.

.: "Der Reflex einer Wiener Lokalsage bei Evliya Çelebi?” Osmanlı Araştırmaları, XI (1991), s. 229-235.

.: "Die diplomatischen Beziehungen zwichen Österreich und dem Osmanischen Reich (Vom Frieden von Zsitva Torok bis zum 1. Weltkrieg)", Osmanlı Araşttrmalar, IV (1984), s. $237-260$. 
Körbl, Hansdieter: Die Hofkammer und ihr ungetreuer Präsident: eine Finanzbehörde zur Zeit Leopolds I., Wien: Böhlau, München: Oldenbourg 2009.

Kraelitz-Greifenhorst, Friedrich von: "Bericht über den Zug des Groß-Botschafters Ibrahim Pascha nach Wien im Jahr 1719", Sitzungsberichte der philosophisch-historischen Klasse der kaiserlichen Akademie der Wissenschaften in Wien, 158/III (1908), s. 1-66.

Kütükoğlu, Bekir: “Ahmed Resmî”, TDV İslâm Ansiklopedisi, II (1989), s. 121-122.

Kütükoğlu, Mübahat S.: "XVIII. Yüzyılda Osmanlı Devleti’nde Fevkalâde Elçilerin Ağırlanması”, Türk Kültürü Araștırmaları, XXVII/1-2 (1989), s. 199-231.

Meienberger, Peter: Johann Rudolf Schmid zum Schwarzenhorn als kaiserlicher Resident in Konstantinopel in den Jahren 1629-43: Ein Beitrag zur Geschichte der diplomatischen Beziehungen zwischen Österreich und der Türkei in der ersten Hälfte des 17. Jahrhunderts, Bern: Herbert Lang/Frankfurt: Peter Lang 1973.

Merian, Mattheus: Theatrum Europaeum oder außführliche und warhafftige Beschreibung aller und jeder denkwürdiger Geschichten [...], 21 cilt, Franckfurt am Mäyn: in Verlegung Matth. Merian 1633-1738.

Meyer, Martin: Diarium Europaeum Insertis quibusdam, maximè verò Germano-Gallo-Hispano-Anglo Polono Sueco-Dano-Belgo-Turcicis Actis Publici, 45 cilt, Franckfurt am Mäyn: in Verlegung Wilhem Serins 1659-1683.

Müller, Klaus: Das kaiserliche Gesandtschaftswesen im Jahrhundert nach dem Westfälischen Frieden (1648 - 1740), Bonn: Röhrscheid 1976.

Neck, Rudolf [u.a.] (Hg.), Österreich und die Osmanen. Gemeinsame Ausstellung der Österreichischen Nationalbibliothek und. des Österreichischen Staatsarchivs. Prunksaal der Österreichischen Nationalbibliothek, 31. Mai bis 30. Oktober 1983, Wien: Österreichische Staatsdruckerei 1983.

Ortaylı, İlber: “Joseph Freiherr von Hammer-Purgstall”, TDV İslâm Ansiklopedisi, XV (1997), s. 491-494.

Pečar, Andreas: Die Ökonomie der Ehre: der höfische Adel am Kaiserhof Karls VI. (1711 1740), Darmstadt: Wissenschaftliche Buchgesellschaft 2003.

Perger, Richard ve Petritsch, Ernst D.: "Der Gasthof "Zum Goldenen Lamm” in der Leopoldstadt und seine türkischen Gäste”, Studien zur Wiener Geschichte: Jahrbuch des Vereins für Geschichte der Stadt Wien, 55 (1999), s. 147-172.

Petritsch, Ernst Dieter: "Tribut oder Ehrengeschenk? Ein Beitrag zu den habsburgisch-osmanischen Beziehungen in der zweiten Hälfte des 16. Jahrhunderts", Archiv und Forschung. Das Haus-, Hof- und Staatsarchiv in seiner Bedeutung für die Geschichte Österreichs und Europas, hg. von Elisabeth Springer, Leopold Kammerhofer, Wien [u.a.]: Verl. für Geschichte u. Politik [u.a.] 1993, s.49-58.

.: "Türken in der Wiener Vorstadt: Osmanische Großbotschaften nach Wien im 18. Jahrhundert," Die Türkenkriege des 18. Jahrhunderts: Wahrnehmen - Wissen - Erinnern, 
hg. von Wolfgang Zimmermann, Josef Wolf, Regensburg: Schnell \& Steiner, 2017, s. $101-128$.

: "Zeremoniell bei Empfängen habsburgischer Gesandtschaften in Konstantinopel", Diplomatisches Zeremoniell in Europa und im Mittleren Osten in der frühen Neuzeit, hg. von Ralph Kauz, Giorgio Rota, Jan Paul Niederkorn, Wien: Verl. der Österr. Akad. der Wiss. 2009, s. 301-322.

Pöllnitz, Karl Ludwig von: The Memoirs of Charles-Lewis, Baron de Pollnitz: Being the Observations He Made in His Late Travels from Prussia Thro' Germany, Italy, France, Flanders, Holland, England, \& c [...], vol. IV, London: Daniel Browne, John Brindley 1745.

Reindl-Kiel, Hedda: "Symbolik, Selbstbild und Beschwichtigungsstrategien: Diplomatische Geschenke der Osmanen für den Wiener Hof (17.-18. Jahrhundert)", Frieden und Konfliktmanagement in interkulturellen Räumen. Das Osmanische Reich und die Habsburgermonarchie in der Frühen Neuzeit, hg. von Arno Strohmeyer, Norbert Spannenberger, Stuttgart: Franz Steiner Verlag, 2013, s. 265-282.

Reiter, Clara: "Vermittler zwichen West und Ost: Hofdolmetscher am Habsburger Hof (1650-1800), Politische Kommunikation zwischen Imperien: der diplomatische Aktionsraum, Südost- und Osteuropa, hg. von Gunda Barth-Scalmani, Gunda Barth-Scalmani, Harriet Rudolph, Christian Steppan, Innsbruck [u.a.]: StudienVerlag 2013, s. 257-273. .: "... wo der Dollmetsch allzeit interpretirt". Das Hofdolmetscheramt am Wiener Hof: Vom Karrieresprungbrett zum Abstellgleis", Lebende Sprachen 58/1 (2013), s. 197-220.

Rudolph, Harriet: "Yeniçağ’n Başlangııında İmparatorlukta Türk Elçileri - 1562'de İbrahim Bey'in Elçiliği Örneğinde İktidarın Sergilenmesi, Yabancıyla Karşılaşma Tecrübesi ve Hatıllama Kültürü”, çev. Ayşe Kılıç, İstanbul Üniversitesi Edebiyat Fakültesi Tarih Dergisi, 63 (2016), s. 127-155.

Schönwetter, Johann Baptist: Ausführliche Beschreibung des Empfangs und Einzugs, welchen der Türkische Groß-Botschafter Vizier Mückerem, Rumeli Valesi Bajefile Taja-Sade, Ibrahim Bassa etc. in die Stadt Wien den 14. Augusti 1719 gehalten, Wien: Schönwetter 1719.

.: Gründ- und umständlicher Bericht von denen römisch-kayserlichen wie auch ottomannischen Groß-Bothschafften: wodurch der Friede oder Stillstand zwischen dem allerdurchleuchtigst-großmächtigst-und unüberwindlichstem römischen Kayser Leopoldo Primo und dem Sultan Mustafa Han III. den 26. Januarii 1699 [... J, Wien: Schönwetter 1702.

Seitschek, Franz-Stefan: "Einige caeremonialpuncten bet(reffend)": kommunizierende Gefäße: Zeremonialprotokoll und Wiener Diarium als Quelle für den Wiener Hof (18. Jh.), (Yayımlanmamış Yüksek Lisans Tezi) Wien: Universität Wien, 2011.

Strohmeyer, Arno: "Die Theatralität interkulturellen Friedens: Damian Hugo von Virmont als kaiserlicher Großbotschafter an der Hohen Pforte (1719/20)", Frieden und Friedenssicherung in der Frühen Neuzeit: Das Heilige Römische Reich und Europa. Festschrift für Maximilian Lanzinner zum 65. Geburtstag, hg. von Guido Braun, Arno Strohmeyer, Münster: Aschendorff 2013, s. 413-438. 
Suner, Suna: "Of Messengers, Messages and Memoirs: Opera and the Eighteenth-Century Ottoman Envoys and Their Sefâretnâmes", Ottoman Empire and European Theatre, vol. II: The Time of Joseph Haydn: From Sultan Mahmud I to Mahmud II (r. 1730-1839), eds. Michael Hüttler, Hans Ernst Weidinger, Wien: Hollitzer Wissenschaftsverlag 2014, s. 83-143.

Suttner, Gustav Freiherr von: Daniel Ritter von Moser. Georg von Gurtner. Beitrag zur Geschichte Wiens im XVII. Jh., Wien: Gerold 1894.

Süreyya, Mehmed: Sicill-i Osmanî, haz. Nuri Akbayar, (eski yazıdan aktaran) Seyit Ali Kahraman, cilt 1-6, İstanbul: Tarih Vakfı Yurt Yayınları 1996.

Şem’dânîzâde Fındıklılı Süleyman Efendi: Şem’dânîzâde Fındıklılı Süleyman Efendi Tarihi: Mür 'i't-Tevârih, haz. Münir Aktepe, c. II./A, İstanbul: İstanbul Üniversitesi Edebiyat Fakültesi Yayınları 1978.

Teply, Karl: Die kaiserliche Großbotschaft an Sultan Murad IV. im Jahre 1628, Wien: A. Schendl 1976.

.: "Karl Eugen Leopoldstätter alias Mehmed Effendi — ein hofbefreiter Kaffeesieder im Wien Kaiser Karls VI.”, Wiener Geschichtsblätter,III/ 27 (1972), s. 374-384.

.: "Nemçe İmparatorlarının İstanbul'a Yolladığı Elçi Heyetleri ve Bunların Kültür Tarihi Bakımından Önemli Tarafları", çev. Bekir Sıtkı Baykal, Ankara Üniversitesi Tarih Araştırmalar, XII (1969), s. 244-263.

..: "Türkische Gesandtschaften nach Wien (1488-1792)", Österreich in Geschichte und Literatur, XX (1976), s. 14-32.

Uluskan, Murat: "Bir Osmanlı Elçisinin Yolculuk Hazırlı̆̆ı: İbrahim Paşa’nın 1699 Avusturya Elçiliği”, Türklük Araştırmaları Dergisi, 20 (2008), s. 251-275.

Veltzé, Alois: “Die Wiener Stadtguardia (1531-1741”, Berichte und Mitteilungen des Altertums-Vereines zu Wien, 36/37 (1902), s. 1-297.

Winkelbauer, Thomas [u.a.] (Hg.): Verwaltungsgeschichte der Habsburgermonarchie in der Frühen Neuzeit, c. I, Hof und Dynastie, Kaiser und Reich, Zentralverwaltungen, Kriegswesen und landesfürstliches Finanzwesen, Wien: Böhlau 2019.

.: Österreichische Geschichte 1522-1699. Ständefreiheit und Fürstenmacht: Länder und Untertanen des Hauses Habsburg im Konfessionellen Zeitalter, Herwig Wolfram (Hg.), c. I, Wien: Carl Ueberreuter 2003.

Wurm, Heidrun: "Entstehung und Aufhebung des osmanischen Generalkonsulates in Wien (1726-1732). Eine Relation Heinrich von Penklers aus dem Jahr 1761”, Mitteilungen des Österreichischen Staatsarchives, 42 (1992), s. 152-176.

Yeşil, Fatih: Aydınlanma Çă̆ında bir Osmanlı Kâtibi: Ebubekir Râtib Efendi (1750-1799), İstanbul: Tarih Vakfi Yurt Yayınları 2011.

Yücel, Abubekir Sıddık: Mühürdar Hasan Ağa’nın Cevâhirüt-Tevârîhi, (Yayımlanmamış Doktora Tezi) Kayseri: Erciyes Üniversitesi, 1996. 